IZA DP No. 5588

Labor Market Adjustment: Is Russia Different?

Vladimir Gimpelson

Rostislav Kapeliushnikov

March 2011 


\title{
Labor Market Adjustment: Is Russia Different?
}

\author{
Vladimir Gimpelson \\ Higher School of Economics \\ and IZA
}

\author{
Rostislav Kapeliushnikov \\ Higher School of Economics
}

\author{
Discussion Paper No. 5588 \\ March 2011
}

IZA

P.O. Box 7240

53072 Bonn

Germany

Phone: +49-228-3894-0

Fax: +49-228-3894-180

E-mail: iza@iza.org

\begin{abstract}
Any opinions expressed here are those of the author(s) and not those of IZA. Research published in this series may include views on policy, but the institute itself takes no institutional policy positions.

The Institute for the Study of Labor (IZA) in Bonn is a local and virtual international research center and a place of communication between science, politics and business. IZA is an independent nonprofit organization supported by Deutsche Post Foundation. The center is associated with the University of Bonn and offers a stimulating research environment through its international network, workshops and conferences, data service, project support, research visits and doctoral program. IZA engages in (i) original and internationally competitive research in all fields of labor economics, (ii) development of policy concepts, and (iii) dissemination of research results and concepts to the interested public.
\end{abstract}

IZA Discussion Papers often represent preliminary work and are circulated to encourage discussion. Citation of such a paper should account for its provisional character. A revised version may be available directly from the author. 
IZA Discussion Paper No. 5588

March 2011

\section{ABSTRACT}

\section{Labor Market Adjustment: Is Russia Different?}

The paper discusses how the Russian labor market has been evolving over two decades of the transition. It starts with tracing key labor market indicators such as employment, unemployment, labor force participation, working hours, and real wages. Their dynamics indicate that the labor market tends to operate in a non-conventional fashion and far from the patterns expected initially. The authors argue that the current Russian labor market represents a peculiar model that is different from what is observed in the rest of Europe outside of the CIS. Having established this, they look at the institutional foundations that make this unconventional performance possible and proceed with discussing political economy and welfare implications. The findings are compared with the experience of other post-socialist countries.

JEL Classification: J8, J21, J31, J62, P20

Keywords: employment, unemployment, wages, labor market institutions, Russia

Corresponding author:

Vladimir Gimpelson

Higher School of Economics

Myasnitskaya Street, 20

Moscow 101987

Russia

E-mail: vladim@hse.ru 


\section{An Adjustment Puzzle ${ }^{1}$}

Before the transition started there was nearly a consensus among experts and politicians about how the Russian labor market would likely evolve in case of a radical economic change. Nobody doubted that a complete collapse of old economic structures designed by the central planners would be inevitable. As a consequence, this would bring drastic displacement of workers and the rapid arrival of high and prolonged unemployment. The first experience of earlier reformers like Poland provided visible and practical arguments in support of this view. Political and social implications of such developments in an economy that was strongly distorted and overindustrialized but had no unemployment-related social experience were expected to be dramatic if not catastrophic. This simple calculus determined the dominant attitude of much of the Soviet political elite in the late $80 \mathrm{~s}$ as well as of the Russian authorities later throughout the transition. The expectation of high unemployment in Russia was also shared by almost all influential international experts. Predictions of unemployment reaching $25 \%$ of the labor force were at that time standard and frequent. ${ }^{2}$ Two major implications followed from this. On the one hand, high unemployment was considered part of the total transition costs borne by the population and all agreed that it should be cushioned; on the other, its arrival could be considered as a credible signal that the radical reform had taken off.

The real story took, however, a completely different route. Most of the early forecasts were contradicted by actual developments and later predictions did not come true either. In short, the

${ }^{1}$ Financial support from the Volkswagen Foundation within the project "The political economy of labor market reform in transition economies: a comparative perspective" and from the HSE Research Program is acknowledged. The authors are grateful to D.Treisman and A.Lukyanova for comments and suggestions.

${ }^{2}$ Most international and Russian experts strongly believed that a sharp jump in open unemployment was unavoidable. An influential study of Soviet economy in late 80s expected the unemployment rate to reach 12 millions by the end of 1992 in case of a modestly optimistic scenario and 13-15 millions if things would go worse (IMF, World Bank, OECD and EBRD. A Study of Soviet Economy. P., 1991, vol. 2). In November 1991, the then Labor Minister A.Shokhin predicted that about 30 millions of Russian workers would lose jobs over the first reform year, while half of them would be destined for long-term unemployment. (Cited by: Clarke, 1998a). 
unprecedented fall in output that took place was not matched by employment adjustment of similar scale. Employment declined but in a piecemeal fashion; unemployment was on the rise but gradually as well. Meanwhile, wages fell dramatically, making a puzzling contrast with the famous wage rigidity axiom. This - unexpected - combination of flexible wages and relatively stable (or, more accurately, highly inertial) employment became a long-term distinctive feature of the Russian labor market for years to come. Dubbed by R. Layard [Layard and Richter, 1994] "the Russian way in labor market adjustment", this model has survived a number of negative and positive shocks and remained largely in action through the 20 years of transition. Very impressive GDP growth in the 2000s sped up wage increase but did not bring proportionately more jobs. The reaction of wages to growing output clearly dominated any employment response. This model was once again put to the test by the recent 2008-09 crisis. It passed the test successfully: labor market outcomes diverted once again from the predicted trajectory. Employment losses, given the GDP fall, were much more modest than those expected while downward wage adjustment was not negligible. It seems safe to say that though macroeconomic shocks were different in their nature and causes, the reactions to them were surprisingly similar.

The idea of a peculiar adjustment model was taken up by a few scholars and got empirical support in a number of studies ${ }^{3}$ [Layard, Richter, 1995b; Commander, Tolstopiatenko, 1996; Gimpelson and Lippoldt, 2000; Gimpelson, 2001; Kapelyushnikov, 2001; Boeri, Terrell, 2002; World Bank, 2003; World Bank, 2005]. Finally, the OECD accepted this as a major story line in the recent labor market and social policy review of the Russian Federation [OECD, forthcoming, 2011].

This chapter explores the evolution of the Russian labor market trying to deconstruct its major determinants and potential implications. In order to unveil the puzzle, we analyze how the Russian labor market has been evolving over time in its major dimensions and what has been shaping these developments. Why was this evolution different (if it was) from what was initially expected by analysts and actually observed in many other transition countries? How did existing labor market institutions contribute to shaping the pattern and to making it so persistent over time? What were some political economy preconditions and consequences? These issues are discussed in more detail below.

\footnotetext{
${ }^{3}$ For convenience we label it as "the Russian model", though in most of the CIS countries national labor markets operate to a large extent in a similar way [Commander, Tolstopyatenko, 1997; Boeri, Terrel, 2002].
} 


\section{A Concise History of the Russian Labor Market Ups and Downs}

There were three stages in the evolution of the Russian labor market, marked by radical shifts in the prevailing macroeconomic regime. The first lasted from 1991 to 1998 and reflected the deep transformational recession that Russia went through. This recession caused a decline in employment, cuts in working hours, and sharp falls in real wages. The second one (1999-2008) saw the dynamic post-recession recovery and a rapid improvement in labor market performance. Finally, the economic crisis of 2008 initiated the third stage, the major properties and final outcomes of which were not completely clear at the moment of writing this paper. In this section we will trace, first, how the Russian labor market evolved and functioned over the period of 1992-2008 and, then, consider the recent (post-2008) tendencies in more details.

\section{Stable Employment, Low Unemployment}

The stylized picture of how the Russian labor market has been performing is presented in Fig. 1. It displays changes in GDP, total employment, hours actually worked and the real wage over the whole period of 1991-2009. Employment has always remained relatively stable and weakly responsive to any major macroeconomic shocks. The transformational recession in the 90s was accompanied by a drastic decline in GDP by $40 \%$ (at the trough of the 1998 crisis compared to 1991) but brought employment down by less than $15 \%$. In other words, each percentage point of lost GDP caused employment downsizing by only $0.3-0.35 \mathrm{pp}$. This contrasted with most of the CEE countries, where the employment change followed the GDP change quite closely [Commander, Tolstopiatenko, 1996; World Bank, 2005]. The economic recovery in the 2000s brought the same asymmetry. While GDP almost doubled by 2008 (relative to 1998), total employment gained 7-8\%. ${ }^{4}$ Low sensitivity of employment to fluctuations in output emerges as a major "trade mark" of the Russian labor market.

As a result, the employment to population ratio (e/p ratio or employment level) has remained unexpectedly high (Fig. 2). It decreased initially by 13 pp from $71.8 \%$ to $58.4 \%$ but then - during the recovery period - reached 69\%, gaining over $10 \mathrm{pp}$. This puts the Russian employment level a little above the OECD average and significantly above the average for other post-socialist countries.

If employment remains high and relatively stable, one might expect unemployment to be effectively contained. Fig. 3 provides visual support for this expectation. Unemployment did not

\footnotetext{
${ }^{4}$ At the same time, the corporate sector continued to downsize!
} 
shoot up in Russia even in the worst economic downturns. It always moved gradually without any sharp jumps, which could be caused by mass layoffs if the latter were used. Having started from $5.2 \%$ in 1992, total unemployment (by the ILO definition) surpassed $10 \%$ only after 6 years of protracted recession and reached (for a short period) its peak value of $13.3 \%$ in 1998 . However, it has never approached peak values typical for some other transition economies (Fig. 4), despite much longer and deeper recession. Given the extraordinary depth and length of the transformational recession in Russia, it is hard to deny that unemployment has remained disproportionately low. The post-crisis (1998) recovery launched a fast decline in unemployment, which more than halved by mid-2008, having reached a decent level of 5.5-6\%.5

This performance was so counterintuitive that a search for measurement errors emerged as the first reaction. Initially, low unemployment in Russia was interpreted by some analysts as a statistical artifact and attributed largely to poor quality measurement or to the inapplicability of the conventional ILO definition to transition economies (Standing, 1996). This hypothesis however did not pass an empirical test (Brown et al, 2006). The Russian unemployment estimates appeared to be quite robust to any modifications in definitions and measurement. Alternative estimates based on broader and more relaxed definitions stayed very close to the then official Goskomstat measures. ${ }^{6}$

Using claimant (registered) unemployment brings an even bigger surprise since this measure has always been extraordinary low. During the period of 1990-2000, it fluctuated within the narrow band of $1-4 \%$ and had fallen under $2 \%$ by mid-2008 (Fig 3). None of the CEE countries could boast such persistently low registered unemployment (Fig.5).

The gap between these two measures of unemployment (the registration-based and the survey-based) has been large and persistent over time. It has never shrunk to less than three times but reached seven times in some periods (Fig. 3). Even more interesting is the fact that these unemployment measures moved along non-coincident trajectories. The first one reached its peak (3.6\%) in 1996 and then started to decline, while the second one kept growing for two more years and reached its peak (13.3\%) only in 1998. In other words, the number of the registered unemployed started to decline at a time when the number of the ILO unemployed was still rising. There were also sub-periods with the opposite dynamics. After 1998, the general unemployment rate sometimes

\footnotetext{
${ }^{5}$ For comparison: in Poland, Slovakia, and Bulgaria, the unemployment rate was close to $20 \%$ over most of the 2000s.

6 This was not the case however with alternative estimates for two other transition countries Romania and Estonia which moved markedly away from the official ones (Brown et al., 2006).
} 
declined while the registered unemployment rate was rising. (Kapelyushnikov (2002) explores why these indicators diverged so much).

\section{Low Inter-Firm Labor Mobility?}

Another tentative explanation for employment stability invoked supposedly low inter-firm labor mobility and emphasized existing barriers, some of which were inherited from the Soviet past. According to this view, low unemployment emerged as an equilibrium outcome of the interaction between dependent workers and paternalistic employers. Russian workers were deeply afraid of entering the external labor market mostly because they highly valued firm-provided social benefits. Therefore, on the supply side, they did their best to keep the jobs they occupied. On the demand side, intrinsically paternalistic employers hoarded labor and rejected any downsizing [Commander, Schankerman, 1997; Commander, Tolstopyatenko, 1997; Friebel, Guriev, 2000].

Certainly, this may have been true of some workers as well as some managers. However, there is little evidence that this argument could explain much of the adjustment process. For example, persistently high worker turnover is hardly supportive of this theory.

In fact, worker turnover in Russia was much more buoyant than in the other post-socialist economies for which detailed data are available [Cazes, Nesporova. 2001; Employment Outlook, 2002]. This resulted in a high proportion of short-tenured workers and a low average tenure. As Lehmann and Wadsworth noted [Lehmann and Wadsworth, 2000], these were "tenures that shook the world". Gross worker turnover measured as the sum of hirings and separations across all firms made up 43-62\% for the whole economy and 45-65\% for industry. As Fig. 6 suggests, in the 90s stability of employment was achieved largely by keeping hiring at high levels, not by low separation rates. Firms could easily downsize proportionately to the output fall by slowing new hiring. Meanwhile, even in the hard times of the 90s, the hiring rate remained at a high level of 20-25\% (relative to average annual employment) thus contributing to relative stability of employment.

Workers' separations from firms were (and are) mostly voluntary (at least they were registered as such) and this fact looked paradoxical as well. Involuntary separations (firings) were relatively rare even when the crisis was the most acute. Those fired made up not more than 1-2.5\% of all employed in firms or 4-10\% of all those actually separated (due to any reasons). Voluntary separated (quitted) workers made up 16-25\% of all the employed or 65-80\% of all the separated.

In sum, available empirical facts provide little support to the hypothesis that stability of employment was generated by low worker turnover and by the "mutual attachment" of workers and managers. Employment remained relatively stable not because of managers who were unable to displace workers and not because of workers strongly opposing any displacement. The actual rate of 
labor turnover would have allowed for any employment level. Therefore, some other forces must be at work here.

Two other interconnected factors may offer more plausible alternative explanation. These are flexible working hours and flexible wages.

\section{Flexible Working Time}

For the first 5 years of the transition, the annual duration of working hours in the Russian economy was shortened by $12 \%$ (Fig. 7). In industry, the decrease made up $15 \%$, or about one seventh of the annual working time. From the mid-90s on, the duration of working time grew rapidly, increasing by 2008 by about 6\% in the whole economy and about 16\% in industry. Fluctuations in hours had a magnitude comparable to that in employment (Fig. 1). If hours had been stable, the change in employment would have been twice as large as that observed in the crisis and in the recovery, other things equal. ${ }^{7}$ By contrast, in the CEE countries the cyclical dynamics of hours were much more muted.

There were multiple reasons for hours to shrink so significantly. In the early transition period (late 80-early 90s), the Russian authorities used legislative cuts of working hours as social and political cushions against mounting hardships. At that time, they had few resources to appease the population facing accelerating inflation and income losses; so free hours were considered a kind of social transfer. The normative duration of the working week was shortened from 41 to 40 hours, minimum holidays were lengthened from 18 to 24 days, additional days of national holidays were introduced, and additional categories of workers got the right to work shorter hours (for the same salary/wage). These social reasons were soon complemented by economic factors that forced firms to cut hours further.

Firms soon realized that cutting hours was one of the cheapest ways to adjust labor costs. They did this in two major ways. They shifted their personnel into administrative leaves (unpaid or partially paid holidays) or into short-time work. Use of these schemes reached a peak by the mid90 s, when $5-7 \%$ of workers were on short-time work and $2-3 \%$ went on forced vacations. ${ }^{8}$ (Every

\footnotetext{
${ }^{7}$ Since these estimates refer to the formal sector, they may overstate actual fluctuations in hours worked. Partially, losses in hours here could be compensated through moonlighting or involvement in the informal sector activity.

${ }^{8}$ Workers on forced leave were subjects to partial compensation which was often withhold due to poor enforcement of this legal norm. This cut down costs associated with the use of forced vacations and stimulated further dissemination of this practice.
} 
year in that period, 6-15\% of workers experienced short-time work and 8-15\% suffered from involuntary leaves.) Flexible hours allowed firms to avoid mass downsizing. Instead, they resorted to shortening working hours for a large portion of the employed population.

However, in 1999 the return of growth changed the trend and the use of short-hours schemes began to shrink very fast. In 2007, less than 0.2 millions workers were affected by short-time work or were sent to unpaid vacations. This constituted less than $0.5 \%$ of all workers employed in Russian firms. Fast recovery in working hours and the wide use of overtime work limited employment growth in the boom period.

\section{Flexible Wages}

Shorter hours brought labor costs down but not enough to accommodate the GDP fall. Downward wage flexibility did the rest.

During the 90s, the real wage lost cumulatively around two thirds of its initial value, demonstrating thus a "great contraction" (Fig. 1). Deflating the average wage with alternative price deflators provides more modest estimates showing that real wages "just" halved [Wages in Russia, 2007] but the sheer fact of a drastic fall is not debated. In any case, the fall in real wages outpaced that in GDP, thus bringing the fraction of labor compensation in GDP down markedly. The restart of economic growth in 1999 launched a steep recuperation of real wages. Inflation remained rather high but nominal wages grew even higher. As a result, during 1999-2007 the real wage grew by 10$20 \%$ annually and cumulatively tripled over this period!

The wage adjustment was achieved in a few ways. The first one was by means of high inflation, which eroded real wages since nominal ones were not subjected to any automatic indexation. Freezes of the nominal wage or its slow increases during multiple and prolonged periods of high inflation resulted in fast devaluation of real labor costs. The largest falls in the real wage always coincided with inflation hikes when nominal wage growth rates lagged far behind CPI rates. Indeed, as can be seen from Fig. 10, "the great wage contraction" was mostly achieved in three big leaps which followed major macro shocks. The first was associated with the price liberalization in 1992; the second one with the so-called "Black Tuesday" in financial markets in October 1994; finally, the third followed the default in August 1998.

The second way (to adjust the real wage downwards) was associated with the specific composition of the wage bill that is typical for the majority of Russian firms. In Russia, a considerable fraction of total wage payments is variable and not fixed in labor contracts. This part includes premiums and bonuses that can fluctuate within a wide band contingent upon general economic conditions and firm performance. (We will discuss institutional properties of the wage 
setting system in more detail in the next section). Linking a significant fraction of workers' compensation to firm performance makes the total wage contingent upon changes in output. In case of downturn, the wage payment shrinks almost automatically, thus containing total labor costs. Meanwhile, workers are likely to enjoy an additional premium in the upturn. As a result, this fraction of wage compensation moves procyclically. As Table 1 documents, in the crisis ridden year of 1998, the most flexible part of the wage made up on average $27 \%$, while in much more prosperous 2007 it reached almost 36\%. A similar regularity is observed across sectors and firms (Table 2). For 2005, in the most prosperous oil/gas extraction and metallurgy sectors, the premiumtype variable fraction (including tariff-related regional allowances) made up58\% and 52\% of the total wage bill! Even in the over-regulated and largely state-run education and healthcare sectors this constituted a quarter and a third, respectively. (Reference to the US?)

Table 1

Composition of wage bill by components, 1995-2009, \%*

\begin{tabular}{lcccc}
\hline Years & \multicolumn{4}{c}{ Proportion in the total wage bill: } \\
\cline { 2 - 5 } & Tariff & Regional allowances & $\begin{array}{c}\text { Extra payments, premiums } \\
\text { and bonuses }\end{array}$ & Other payments \\
\hline 1995 & 53,0 & 15,8 & 28,2 & 3,0 \\
1998 & 52,4 & 14,9 & 27,3 & 5,4 \\
2000 & 49,2 & 15,1 & 32,7 & 3,0 \\
2002 & 50,1 & 14,1 & 32,9 & 2,9 \\
2005 & 47,8 & 14,2 & 35,1 & 2,9 \\
2007 & 49,2 & 12,1 & 35,6 & 3,2 \\
2009 & 52,5 & 11,4 & 33,3 & 2,9 \\
\hline
\end{tabular}

* Net of compensation for not working time.

Source: Rosstat.

Table 2

Composition of wage bill by major components, some sectors, 2005, \%

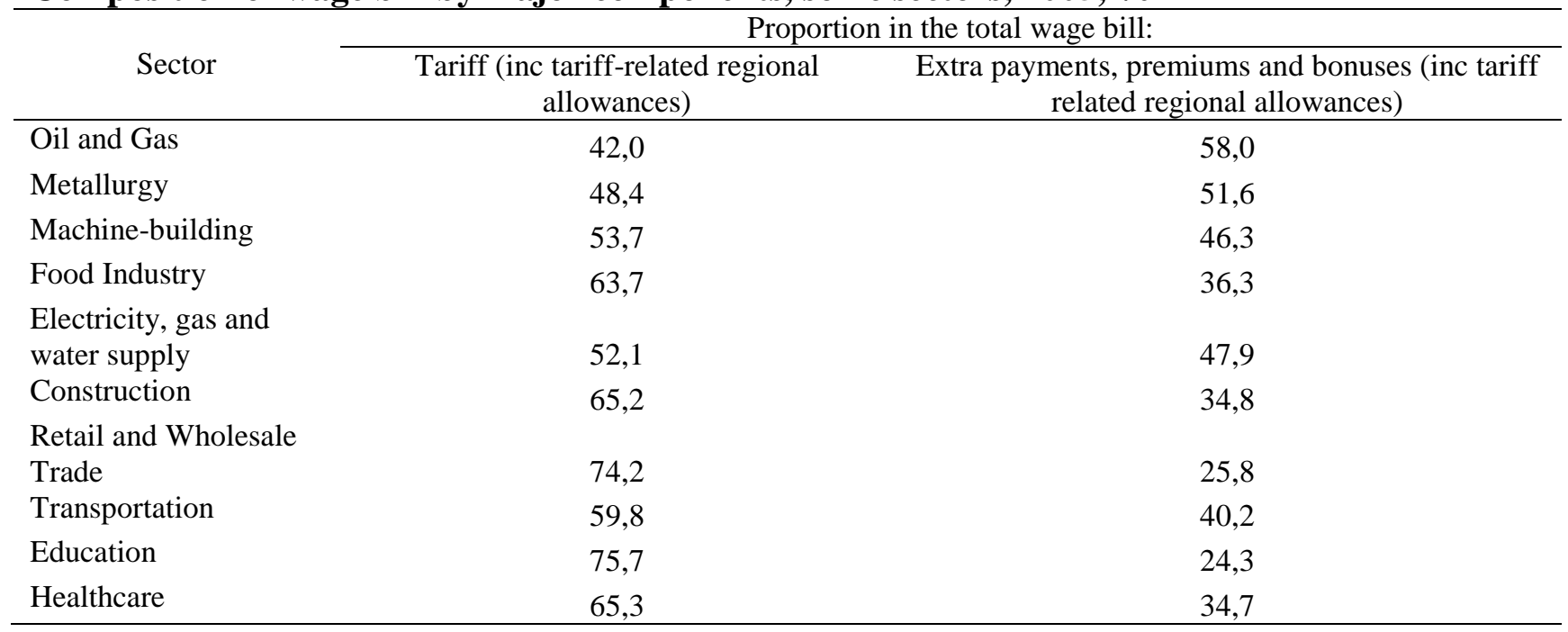

Source: Rosstat. 
The third approach to wage adjustment was paying late. Wage arrears grew explosively over the 90s and were widely discussed in the research literature [Clarke, 1998b; Desai, Idson, 2000; Earle, Sabirianova, 2000; Earle, Sabirianova, 2002; Earle, Sabirianova, 2004; Lehmann, Wadsworth, 2001; Lehmann, Wadsworth, Acquisti, 1999]. They emerged in early 1992 and peaked in mid-1998. At that time, about two thirds of all wage and salary workers were paid late. In real terms, the accumulated value of arrears increased by tenfold from the start to the peak (Fig. 9). In 1992-1993, the stock of unpaid wages amounted to under one fifth of the monthly wage bill; by the end of 1998 it accounted for over 1.5 times the monthly wage bill [Wages in Russia, 2007]. However, as soon as the economy returned to the path of economic growth wage arrears began to dissipate rapidly. By mid-2008, they made up under $2 \%$ of the monthly wage bill, while the proportion of workers affected was less than $1 \%$. In other words, delaying wages appeared (for firms) as an efficient instrument of wage flexibilization during the crisis and virtually disappeared when the crisis receded.

Finally, firms might (and in fact, they did) use informal (undeclared) payments. This increased wage flexibility even further. The unofficial part of wage payments made up around $50 \%$ of the official (declared) wages and stayed practically constant over the whole period [The Russian Statistical Yearbook, various issues]. These payments not bound by any formal constraints were especially sensitive and responsive to any change in labor demand and reacted immediately.

In downturns, simultaneous use of all these instruments (inflationary depreciation of real compensation, cuts in premiums, wage arrears and shrinkage of shadow wages) contained labor costs and made mass downsizing not vitally important. Workers losing earnings activated their exit behavior. As a result, employment adjustment was allowed to proceed gradually and sharp outbursts of open unemployment were prevented. As Boeri and Terrell noted about labor market adjustment in the CIS region, “... the flexibility of wages clearly did matter... The tremendous decline in wages in the former Soviet Union helps explain why employment declines in these countries early in the transition process were relatively muted, while the lesser decline in wages in central and eastern Europe helps explain why adjustment in these economies took the form of larger declines in employment" [Boeri \& Terrell, 2002, p.60]. When the economic situation tended to improve, firms could minimize using these instruments and, therefore, they raised the payable wage. Again, positive shocks were met by (positive) wage fluctuations but not by any sizable changes in employment.

The contrasting behavior of wages and employment is well illustrated by Fig.10, which presents their monthly dynamics over 1991-2009. If the former reacted immediately to any shocks, the latter remained largely insensitive and unaffected. The dotted broken line for real wage 
dynamics reconstructs in detail the drastic ups and downs in the Russian economy throughout the transition. By contrast, looking at the smooth line for employment, one could hardly imagine those dramatic events that went one after another during the period. A standard textbook view would suggest that the picture should be rather the opposite.

\section{Did the 2008-09 Crisis Change the Mode of Adjustment?}

The 2008-09 economic crisis can be considered an additional robustness test for the model. It reduced Russian GDP by 7.9\% in 2009 and called for a large adjustment in the labor market. Institutional changes in the Russian economy (including the ongoing battle of the government for "better enforcement", persistent increases in administrative pressure on business, the retirement of the old generation of paternalistically oriented "red directors" etc) coupled with substantially lower inflation might raise doubts that behaving in the old way would be feasible for most firms. Against these expectations, available evidence suggests that key labor market indicators tended to behave largely as before.

Indeed, total employment declined only by a modest $2.2 \%$ in 2009 (Fig. 1). (True, in the corporate sector net job losses were somewhat larger $-3.5 \%$; the difference can be attributed to the fact that the outflow from the corporate sector was partially absorbed by the informal sector and indicates the high shock absorbing capacity of the latter.)

As for unemployment, it grew from 6.4 to 8.4\%, or by 2 pp, in 2009 compared to 2008 (Fig. 3). The difference between the peak and the trough monthly values (seasonally adjusted) was larger and amounted to $3 \mathrm{pp}$ (Fig. 11). However, already from the middle of 2009, general unemployment tended to go down; it reached $8 \%$ by the end of that year and fell further to $7 \%$ by the end of 2010 . Change in registered unemployment was more dramatic (Fig. 11). It grew from $1.8 \%$ for the precrisis peak to $3.1 \%$ for the crisis trough (these are seasonally adjusted monthly values), which meant an increase in claimant unemployment by almost $70 \%$. However, this jump was caused partially by institutional factors, including a sharp rise in value of the unemployment benefit (UB) and easer access to them in early 2009. Moreover, even with this additional inflow the level of registered unemployment remained low for any phase of the business cycle, the acute crisis being no exception. Again, the fall in employment and rise in unemployment appear disproportionately mild compared to the depth of the new output contraction.

A closer look into worker turnover shows which factors were likely to be responsible for the observed employment reduction. Paradoxically, in the crisis-ridden year of 2009 total separations were even less numerous than in the economically favorable year of 2007: these were 30.5\% against $31.3 \%$, respectively (Fig. 6). In contrast to separations, total hiring decreased markedly from $31.0 \%$ 
in 2007 to $26.2 \%$ in 2009 . This illustrates the regularity already observed: given the high rate of worker turnover, Russian firms can effectively downsize just by temporarily freezing new hires without active use of involuntary labor shedding.

The composition of outflows from jobs was also puzzling since the crisis did not bring many more layoffs. In 2009, these accounted for merely $7 \%$ of total separations and affected only $2 \%$ of the workforce. Moreover, the number of collective dismissals almost did not change and concerned under $0.5 \%$ of the workforce, as in the pre-crisis period. Therefore, Russian firms facing a demand shock kept avoiding layoffs while using - as they did before - alternative cost containment instruments and approaches.

One of these alternatives concerns changes in working hours. The underemployment overhang in 2008-09 generated by the discrepancy between changes in GDP and employment was of the scale that was observed in the mid-90s. In 2009, the annual duration of working hours per worker in the economy was less than in the previous year by $2.4 \%$. The difference was $4.8 \%$ in industry and $6.2 \%$ in manufacturing, all due to expansion of various well-known short hours regimes (Fig. 7). In the beginning of the crisis about $20 \%$ of the workforce, in 7 major sectors of the Russian economy for which monthly statistics are available, worked shortened weeks or took involuntary or quasi-voluntary leave. This expansion was driven largely by employers' initiative and many workers had to accept this option, given the lack of better alternatives.

What was the wage response? Did it continue to demonstrate striking downward flexibility? Not as much as during the transformational recession of the 90s. Two major constraining factors were at work here. First, inflation, though it remained relatively high, was much lower than that accompanying the previous crisis episodes. For this reason, its contribution to the depreciation of real wages was much more modest. Second, the state increased enormously its administrative pressure on firms trying to prevent any use of wage arrears. Though this instrument was still in use, the scale was very limited (Fig. 12). After a small increase in the first crisis months, wage arrears soon started to dissipate and already in 2010 returned to their pre-crises level.

However, other instruments ensuring wage flexibility remained in action. In late 2008-early 2009 , cuts in nominal wages by $10-20 \%$ were observed in most parts of the private sector, while in others they were effectively frozen. In nominal terms (!) wages (seasonally adjusted) decreased in Construction (F) and Financial Intermediation (J) by 21\%, in Manufacture of Mineral Products (C23) - by $15 \%$, in Transport Manufacturing (C34)- by 10\%, in Metallurgy (C27), Machinery (C29), Manufacture of Wood and Wood products (C20)- by 8-9\%, in Transportation (I) - by 7\%, in 
Wholesale and Retail trade $(\mathrm{G})-$ by $6 \%$, in Manufacture of Chemicals and Chemical products (C24) and Manufacture of Electrical Products (C31) - by 4-5\%.

Though the nominal wage started to rise soon, it lagged behind inflation. This resulted in a real wage decline of $3.5 \%$ in 2009 . By contrast, the real wage growth before the crisis was about 10$15 \%$ annually over almost 10 years (Fig. 13). ${ }^{9}$ This shift from growth to decline was impressive by any standards (OECD, 2011), though it may not impress Russians much, given that the macroshocks in the 90 s caused real wage cuts of $25-30 \%$.

Table 3 decomposes labor market adjustment during the 2008/09 crisis by major factors. It suggests that employment, working hours, and wage adjustments made comparable contributions. Again, the employment decline was much less (by three times) than it would have been had hours and wages not changed. Employment to output elasticity stayed within the same range as in the 90s. As already mentioned, while GDP declined by 7.9\%, employment fell by just 1.7\%; industrial output fell by a very impressive $10.0 \%$, while industrial employment downsized by $5.9 \%$; output in manufacturing decreased by a quite dramatic $15.8 \%$ while its employment shrank by $7.2 \%$. So, each pp of output decline in the economy at large brought employment down by $0.22 \mathrm{pp}$, while in industry this was by $0.46-0.59 \mathrm{pp}$.

Table 3. Annual changes in output, employment, working hours and real wages, 2009 to 2008, percentage points

\begin{tabular}{lcccc} 
& Output & Employment & Working hours & Real wages \\
\hline Total economy & -7.9 & -1.7 & -2.4 & -3.5 \\
Industry & -10.0 & -5.9 & -4.8 & -5.7 \\
Manufacturing & -15.8 & -7.2 & -6.2 & -7.2 \\
\hline
\end{tabular}

This simple analysis suggests that "the Russian model" is more alive than dead though in a slightly modified form. Once again the Russian labor market demonstrated its ability to accommodate major negative shocks without large losses in employment and drastic increases in unemployment. ${ }^{10}$ This does not mean, however, that this persistent adjustment mode is close to the optimal, given all welfare and productivity related considerations.

\footnotetext{
9 The wage dynamics we observe seemed to be partially distorted by state intervention into public sector wage setting. In 2009, the Russian Government raised salaries in the sector by $30 \%$. Without this, the overall real wage decline would be much larger.

${ }^{10}$ Reactions to the economic crises of 2008-09 in many developed countries (for instance, Germany) differed from those used previously. Hours adjustment as a way to mitigate shock and to contain unemployment became quite popular [Cahuc P., S. Carcillo, 2011].
} 


\section{Institutional Foundations of the Reverse Employment/Wage Asymmetry}

If wages and employment behave as described above, one may expect that these outcomes are effectively shaped by the acting labor market institutions. In order to channel firms' and workers' behavior in this direction there must be an institutional framework that slows down employment adjustments but leaves wage fluctuations largely unconstrained.

This raises a big question: do the Russian labor market institutions trade off employment against wages? If yes, then how? These institutions are usually strongly interconnected and complementary; therefore, their effects on employment cannot be easily disentangled from their effects on wages. Employment effects of regulations are usually much more pronounced when wages are sticky; otherwise, flexible wages may decrease some adverse impacts on employment [Lazear, 1990, p.702]. However, keeping all this in mind and preserving a high level of generality, we can say that employment protection legislation (EPL) is largely "responsible" for allowing (or not) employment fluctuations, while minimum wage and wage-setting institutions, as well as regulations governing unemployment benefits (UB), affect wage outcomes.

The choice of a particular wage-employment trade-off is a political economy problem and reflects particular social and political preferences. In Russia, this institutional choice seemed to be made early in the transition and was path dependent in relation to the late Soviet period.

\section{Employment regulations}

Institutionally, the scope for employment flexibility is largely determined by firing costs introduced by the employment protection legislation (EPL). On the one hand, high firing costs contain quantitative fluctuations and introduce additional inertia into employment. On the other, equilibrium employment under high firing costs appears to be lower than it would otherwise be [Bertola, 1990; Lazear, 1990; Heckman, Pages, 2003].

In Russia, the EPL constituted an important part of the labor legislation accumulated in the Code of Laws on Labor (KZOT). This code was initially developed in the specific context of the central planning system, was in force throughout the 90s, and, with multiple partial amendments, continued to operate until 2002. Its major explicit objective was to limit flows of workers in the state-owned economy, which was chronically ridden by labor shortage. The updated Labor Code came into effect in early 2002 and was amended further in 2004 and 2006. Though some contradictory and obsolete requirements were abolished, the EPL part of the Code changed little. 
Born as a hard political compromise, it basically inherited multiple rigidities from the old legislation.

The picture of the Russian EPL can be summarized briefly by using various integral EPL indices that allow cross-country comparisons. Existing indices tend to confirm that the Russian EPL, as written in the law, should be considered very stringent. The World Bank in its "Doing Business"2007 survey estimated the rigidity of employment (rigidity of hirings, firings, and working hours) in Russia, assigning 44 points against 30.8 for the OECD on average [World Bank, 2007]. The deviation from other countries is even stronger if we refer to indices suggested by [Botero et al., 2004]. In this case, Russia earns a value of 0.83 against the median value of 0.44 (these scores relate to the 90s when the old KZOT was still in force). This ranked Russia first on the list of the countries with the most rigid EPL. The OECD tends to evaluate the Russian EPL as flexible, though it admits excessive rigidity in relation to short-tenured workers on permanent contract [OECD, 2010 $]^{11}$. Job protection for permanent workers gets a score of 2.8 against 2.1 (on the OECD scale) for the OECD average. Just three OECD countries (Portugal, the Czech Republic, and Slovenia) have a higher index on this dimension.

Some ambiguity in the evaluation of nominal EPL strictness for Russia relates to the use of fixed-term (FT) contracts and temporary work agencies (TWA). Though some consider the Russian legislation with relation to FT contracts extremely flexible, their legal use is strictly limited by a closed list of exceptions. Courts, if law suits are filed, tend to take the workers' side and alter the contracts to make them permanent (open-ended) contracts. Since the RF LC includes no provisions concerning TWA activity, some experts interpret this as a nearly laisser-faire regime. However, it would be more correct to say that the use of TWA work is de facto prohibited by the law although this prohibition is often poorly enforced.

\section{Minimum wage}

The minimum wage sets a wage floor and can, therefore, constrain downward wage flexibility. In Russia, during most of the transition period, the minimum wage was fixed at a low level and was hardly binding for the majority of firms in the economy. Indexation was irregular, lagged far behind inflation, and had a short-run effect on relative earnings. The evolution of the minimum to average wage ratio is presented in Fig. 14. It was usually less than $10 \%$ and fell under

\footnotetext{
${ }^{11}$ Some recent studies also consider the Russian EPL flexible or even extremely flexible. However, we believe that they misinterpret some elements of the Russian legislation. For their critical appraisal see (Kapelyushnikov, 2011).
} 
$5 \%$ for some time in 1999-2000. Starting from Jan 1, 2009, the minimum wage almost doubled in nominal terms from $\mathrm{Rbl} 2,300$ to $\mathrm{Rbl} 4,330$. Initially the ratio increased to a quarter of the average wage, but it decreased again since then. During the whole transition period, it was much lower than in the EEC.

Why was the Russian Government so committed to a low minimum wage policy? A few considerations might simultaneously be at work here.

First, this could be motivated by fiscal constraints. In the 90 s, multiple social benefits were tied to the minimum wage and any increase of the latter gave an impetus to inflation of social spending. Second, any rise in the minimum wage (abbreviated in Russian as MROT - "minimal pay level") shifted upward the whole pay scale in the public sector, thus also inflating total spending. Recall that in the 1990s the general government budget was running a large deficit, though it turned into surplus by the mid-00s. Third, the enormous heterogeneity of the Russian regions implied that any large increase in the minimum wage could severely lower employment in the most depressed regions. Since the average wage in better performing regions was more than three times higher than in the worst performing regions, the MROT equalled a mere $15 \%$ of the average wage in the first group (such as Moscow or Tyumen) but might easily exceed 50\% in the second (containing the autonomous republics of the North Caucasus, among others). ${ }^{12}$

Taken together, these considerations might explain why the Government stuck to a policy of a low minimum wage. It initiated upward adjustments only when it considered this politically beneficial. As might be expected, such moments usually coincided with approaching elections.

\section{Unemployment benefits}

Another upward pressure on the wage floor can be generated by unemployment benefits (UB) since these also tend to affect the reservation wage and ultimately the whole wage distribution. Russia entered the transition having no open unemployment and consequently no social protection

${ }^{12}$ Until 2006, MROT was set by the federal authorities at the level that was uniform for all regions. According to 2006 amendments to the Labor Code, in addition to the federal MROT, each region should introduce its own - regional - minimum wage not lower than the MROT. By the time of writing, we had no hard data to evaluate an impact of this new norm. Some regions refrained from raising regional minimum wage level above the MROT level, others raised it not substantially, still others raised it but with significant exceptions. One of the highest minimum wages was in Moscow but even here it made about $25 \%$ of the average wage. 
targeted at the unemployed. The safety net to cushion emerging social costs had to be created from scratch and without delay. Its designers were caught between expectations of high unemployment and fears of being too generous. Such fears were warranted given the Polish experience in the early transition. As already mentioned, fears of very high unemployment did not come true, while the safety net emerged with multiple loopholes and was far from generous. Throughout the 90s, the share of annual GDP budgeted for labor market policies remained remarkably low. It constituted less than one-half of 1 percent, while expenditures of this sort in Hungary or Poland reached 1.3 and 2.25 percent, respectively (UN Commission for Europe, 2003). In the 2000s, this share became almost negligible. Total spending on passive and active labor market policies remained less than $0.1 \%$ and it only approached $0,2 \%$ in the crisis 2009 due to additional spendings.

In this context, the UB level was unable to act as an effective wage floor. Its evolution (Fig. 15) tells us basically a story similar to that of the minimum wage. The average UB to average wage ratio reached a peak of $30 \%$ in 1998 but subsequently declined gradually. It was under 10\% before the 2008 crisis. The increase of the maximum UB value to 4,900 Rbl in late 2008 did not change the ratio significantly. Low UB levels and the lack of job vacancies at the disposal of the Public Employment Service (PES) discouraged job-seekers from applying to this agency and contributed to low claimant unemployment. Again, the combination of fiscal constraints and heterogeneity in the regional labor markets tied the hands of government with regard to any significant upward UB adjustments.

Summing up, in Russia the wage floor has always been (and still is) effectively low for various reasons. If wages tended to decline, the low wage floor did not prevent deep falls.

Two-tier wage structure

In Russia -in both the private and public sectors - the individual wage typically has a twotier structure. The first part (tier) is fixed (basic, tariff-based) and rigidly contracted, while the other one is variable and therefore flexible. ${ }^{13}$ As Table 2 illustrates, it is large in all sectors including the public one. As mentioned earlier, the variable part includes various bonuses or wage premiums which in sum indirectly reflect financial performance of the firm and, since performance may vary over time (and across firms), it tends to grow in good times (and in good firms) and shrink in bad times (and in bad firms). The public sector (containing public universities and schools, hospitals, museums, research institutions, etc, which are funded from the federal or local budgets), though

${ }^{13}$ Here we do not mean that the variable part is informal and is paid "in an envelope". If this informal component in a particular job exists, it adds the third and the most flexible component. 
heavily regulated by the government, follows basically the same two-tier wage-setting logic as the private sector. Here, the variable part is linked to revenues of regional/local budgets. If the latter get richer, public sector workers (funded from these budgets) enjoy higher earnings, other things equal [Wages in Russia, 2007]

The large and persistent variable component in the two-tier wage structure works as an automatic risk-sharing device in the face of high uncertainty in the market environment [Bigsten et al., 2003]. This assumes an implicit contract between risk-averse workers and managers who appear also to be risk-averse. In other words, a significant portion of labor market related risks is shifted onto workers.

\section{Trade unions and wage agreements}

Trade unions (TU), if they are numerous and powerful, constrain wage flexibility. TU usually bargain for wages but leave some room for managers to decide on employment adjustment (governed by the EPL).

A superficical glance at the Russian labor market would suggest a very rigid corporatist arrangement inherited from the Soviet past. If to judge using conventional measures, the wagesetting in Russia seems to be highly centralized and coordinated [Cazes, 2000]. It has a multi-layer bargaining structure with the Tripartite Commission on the top (adopting national level tripartite agreements), industry level tariff agreements between employers' associations and sector-specific trade unions, and in addition tripartite agreements at regional level. ${ }^{14}$ Within this framework, firms would seem to be completely constrained in their wage policy; almost no room is left for either upward or downward decentralized wage adjustments. However, this conclusion would be completely misleading since it ignores important nuances concerning the functioning of the system. As already mentioned, over one third of the total wage is not contracted at all and remains contingent upon performance. Additionally, TU initiatives (at any level) are easily blocked by the government and are accepted only if the government agrees. This makes the whole corporatist structure largely decorative and shallow [Ashwin, Clarke, 2002; Clarke, 2007; Denisova, Svedberg, 2007].

TU density, which was close to $100 \%$ at the start of the transition, has eroded gradually, though in the corporate sector it still remains rather high. The major TU (abbreviated as FNPR in

\footnotetext{
${ }^{14}$ In 2010, there were 61 industry-level and 75 regional level agreements while the total number of firm level collective agreements was around 170 thousands (FITUR reports).
} 
Russian or FITUR in English) ${ }^{15}$ claims to represent about $70 \%$ of workers in large and medium sized firms. How many of these members exist on paper only remains, however, a big question [Ashwin, Clarke, 2002]. In the 2000-s, annual losses in membership made up around 5\% or 1 million members, as reported by FITUR. Outside the segment of large and medium sized firms (employing about $50 \%$ of all employed in the economy) the TU do not seem to exist at all.

The low level of union voice and mobilization capacity derives partially from structural changes within the labor force. Among these were the employment shift from large-scale industry to the service sector, where small firms prevail; the growing non-unionized sector; rising heterogeneity and the segmentation within the unionized sector.

High wage inequality in the unionized sector, the two-tier wage setting system (with a large upper tier), and low strike activity are clear indicators of low TU capacity. Otherwise (if the TU were stronger and more influential), one might expect to see lower variation in wages, a smaller variable part (if any) in the wage structure, and higher frequency of strikes across the economy compared to that observed at any moment during the period.

\section{Efficiency of enforcement}

This is one of the key features making the Russian labor market what it is. Any discussion of the impact of regulations on labor market performance usually implicitly assumes that laws and contracts are fully enforced. If this is not the case, actual outcomes can deviate markedly from what is normatively expected. Incomplete enforcement is typical for many countries and the transition economies are salient in this respect. On the one hand, weak enforcement deregulates the labor market; on the other hand, it increases uncertainty for firms and workers

In this regard, the Russian case is of special interest due to the high heterogeneity of the country and the lack of a tradition of obedience to the law. As M.Saltykov-Tchedrin ${ }^{16}$ put it in the XIX century, «the stringency of Russian laws is offset by their non-observance». Non-observance of laws and rules is a key element of the observed flexibility.

Weak enforcement (which reflects weak capacity of the state) concerns all major wage and employment regulations. As already discussed, wages are not paid on time and in full, the variable part of wage payments is usually not fixed by a contract, working hours may be shorter than the

\footnotetext{
${ }^{15}$ Alternative TU are not numerous and their activity is concentrated in a few narrow sectors or even firms.

${ }^{16}$ Attributed to M. Saltykov-Tchedrin (a famous Russian writer (1826-1889), who also served as a vice-governor in one of the provinces of the Russian Empire).
} 
bottom limit permitted by law or much longer than the upper limit, the minimum wage is not binding, firings are substituted by semi-voluntary quits, just to mention a few examples. The systemic imitation of strong governance does not prevent the adjustment from proceeding beyond and despite formal rules. This may explain the puzzling association between stringent regulations (on paper) and remarkable flexibility (in practice).

Poor observance of the law is well recognized by all labor market agents, as illustrated by data from a specially organized survey. According to this survey, the proportion of enforcers believing that EPL observance does not pose any problem is strikingly small. This opinion is shared by just $3 \%$ of the judges, $8 \%$ of the employers' representatives, and by $3 \%$ of the TU regional leaders that were surveyed. None of the surveyed labor inspectors or the PES top officers took this position. If measured on a 7-point scale with the maximum given to complete observance, the Russian regions vary from 2.3 to 5.0 points. Most of the averages are under 4 points, while the employers only assign just a little more than that [Gimpelson et al, 2010].

In the early 2000s, the Russian authorities announced far-going plans to bring "more law and order" into all areas of economic life, including the labor market. In the context of these measures, not paying wages on time became a serious crime punishable by imprisonment, for example. This helped to curb the wage arrears epidemic but brought little law obedience in other areas. On the contrary, firms began to seek "refuge" in less regulated and not so well monitored areas.

Obviously, such extralegal (beyond the rules) adjustment creates an uneven playing field and generates uncertainty for firms and workers. Gimpelson et al (2010) documents that in Russia EPL enforcement varies significantly across regions, localities, and firms. This paper argues that the variation in enforcement across regions is translated into variation in labor market performance, if the endogeneity of enforcement is accounted for. Stricter enforcement raises EPL costs, other things equal, affecting employment negatively and unemployment positively. Inter alia, this implies that the EPL is stringent enough, if the formal regulations are thoroughly applied. The cost of this stringency would be in lower employment and higher unemployment than was actually observed.

In practice, the active bypassing of the formal rules by firms contained the costs of labor turnover. Firms could easily get rid of some workers or decrease wage costs for others and, at the same time, this allowed them to hire new workers with little fear of getting stuck with these workers (and associated costs) in case of a sudden downturn. 


\section{Political Economy Perspective}

Fig. 16 summarizes schematically the modus operandi of the Russian labor market and illustrates why adjustments on the price margin (through wage) or the intensive margin (through working hours) might dominate adjustments on the extensive margin (through the number of workers). However, for this modus operandi to persist, major agents (workers, firms and the Government) must expect that associated benefits exceed total costs. For workers, fear of unemployment, weak voice, and uncertain outside options help reconcile them to wage cuts. Firms are ready to accept this system because it enlarges their adjustment space and allows the shifting of some labor market risks to other parties. Key benefits for the government in this model can be seen in containing unemployment, which was considered a serious threat to "social and political stability", and in the possibility to delay structural reforms that might have brought more unemployment. Thus workers, firms, and the government each have their own reasons for favoring this model.

As analysis for Russia and other countries demonstrates, fear of unemployment may have a strong impact on workers' behavior. If workers are afraid of unemployment, they are more likely to accept flexible wages. ${ }^{17}$ Ultimately, employment in this case, inter alia, can be higher than otherwise would be the case. In Russia, such fear has always been very strong against the background of low UBs and the impotent PES. Using household survey data for 1994-2008, we documented that Russian workers express very strong fear of losing their job and, if this happens, of not finding a new one of similar quality [Gimpelson, Oshchepkov, 2010]. Fear indexes for Russian workers are much higher than those in the OECD countries, but are close to those observed in Latin America.

Strong and persistent fear may have important and far-reaching implications. First, fear works to remove the source of fear. Containing wage costs, it helps to keep unemployment at a lower level. Secondly, fear of unemployment may create demand for populist policies including the further strengthening of job protection regulations. More protective rules, in their turn, bring a reduction in formal jobs and, therefore, lead to a new fear spiral. This vicious circle is hard to break. ${ }^{18}$ The third point relates to prospects for institutional reforms more generally. The Russian

17 Blanchflower, 1991. On Russia: Gimpelson, Kapeliushnikov and Ratnikova, 2003; Linz and Semykhina, 2008.

18 There is an analogy with relationships between trust and demand for regulation. As (Aghion et al, 2010) argue, low trust societies are unable to solve many emerging problems and demand, therefore, 
authorities are afraid of social protests and therefore may opt for freezing any reforms that are likely to activate displacement.

Another implication of the Russian model is that individual exit strategies strongly dominate collective voice. On the one hand, workers' voice remains weak, due to the low political influence and mobilization capacity of trade-unions; on the other hand, intensive labor turnover implies the popularity and availability of exit.

Strikes in contemporary Russia are extremely rare; activity was somewhat higher in the 90s, but then declined in the 2000s with the return to the growth path and virtual disappearance of wage arrears (Clarke, 2007). Even more important, there was no revival in strike activity during the 200809 crisis, despite a visible deterioration in wage and employment conditions for a large part of the labor force. ${ }^{19}$ Occasional protests of workers in mono-industrial towns that were sparked by the crisis (and which attracted significant public attention at the time) were relatively quickly and easily neutralized by focused governmental interventions. The problem here is not just that voice has been weak (as it, in fact, has) but that the exit strategy for workers seems, on average, to be much cheaper in relative terms.

The redistributive implications of this model differ from those incurred by the model that uses quantitative adjustment. The latter assumes that workers are fired in bad times and are hired in better times. Those fired (and then hired) bear a major burden (or gain, consequently) but this group is relatively small, while "stayers" remain almost unaffected. As a result, costs and benefits are highly concentrated. In contrast, the Russian model tends to spread adjustment costs over a larger part of the labor force. This derives from the fact that lay-offs are relatively rare while wage decreases or hours cuts in crisis times affect almost everybody (though to different degrees). If a median voter's preferences are shaped significantly by fear of unemployment, he/she may feel happy that unemployment has passed by with little impact. A symmetric picture emerges in the growth episodes when the employment creation in the formal sector of the economy remains frozen or even negative but wages increase quite fast and across all sectors and firms. Here the median voter belonging (so far!) to the segment of large and medium size firms would again feel happy.

for more governmental regulation. More regulation, especially if it fails (what happens frequently), tends to destroy trust. As a result, low trust leads to more regulation and we get full circle.

${ }^{19}$ Partially this could be explained by multiple stipulations hindering initialization of strikes, which were introduced in the new 2001 Labor Code. 
There are also a few reasons for firms to make a similar choice. First, they have an almost automatic built-in stabilizer working through procyclical movements in labor costs. Firms can easily rely on this option since they feel little competitive pressure to modernize or restructure (otherwise, they would be forced to restructure their manpower keeping competitive wages). Second, as suggested by surveys, enterprise managers consider layoffs as a very costly and conflict prone adjustment measure. These perceptions may also shape - other things equal - preferences for price adjustment, leaving layoffs as a last resort option. Third, this model does not exclude quantitative adjustment, but channels it into the mechanisms of individual quitting or shifts it beyond formal regulations.

As for the government, it feels quite satisfied with this model largely because unemployment tends to stay at a low level. This minimizes possible political risks associated with quantitative adjustment given that strong fear of unemployment is so widespread in the Russian society. In addition, low unemployment contains the fiscal costs associated with social protection of the unemployed. Last but not the least, the impressive wage growth across the board in upturns is likely to be translated into high Presidential and Government approval ratings [Treisman, 2010]. ${ }^{20}$

This coincidence of preferences among major actors forms a robust institutional equilibrium strengthening path dependence and making a retreat from it difficult and costly.

\section{Conclusion: A Balance-Sheet of Pros and Contras}

What is the resulting pay-off generated by this model? The emerging balance-sheet is ambiguous. Since actual gains and losses produced by this type of labour flexibility are closely intertwined and hard to disentangle, its welfare implications turn out to be mixed.

On the positive side:

$=$ the labour market has been performing unexpectedly well if one judges on the basis of all major quantitative employment and unemployment indicators. Russian-style flexibility allowed for keeping employment and participation rates high enough while unemployment never approached

${ }^{20}$ This might also explain a key political approach of the Government to managing the 2008-09 crisis - to provide a short-term shelter (whatever it costs) - to the public from the full pain of the crisis. Financial resources previously accumulated allowed to mix policies targeted at supporting employment and at retaining wages in large firms and the budgetary sector. 
any dramatic levels. This model helped to weather the storm of the early transition and to avoid mass displacement in all consequent crisis episodes;

$=$ from the macroeconomic point of view, low unemployment has positive fiscal externalities (contained budgetary expenditures on unemployment protection);

$=$ from the social perspective, adjustment time for individuals and households was significantly stretched, allowing them to avoid joblessness and to retain social ties, while guaranteeing them minimal income, etc. Large scale social conflicts associated with mass displacements were avoided;

$=$ low productivity workers are not ousted from the labor market and may look for an alternative job, preserving low paid employment;

$=$ the prevalence of individual exit strategies over collective actions worked as a shock absorber, partially containing social tensions and keeping them in hidden form. Social conflicts did not become open and large scale even against strong macroeconomic shocks.

On the negative side:

$=$ the Russian model does not facilitate enterprise restructuring. On the contrary, it helps to save old jobs at the cost of creating new ones. Supporting (in various ways: through wage arrears or unpaid leaves, by blocking lay-offs, etc) inefficient firms it keeps them afloat, preserves large segments of low productive and technologically obsolete jobs. Slow job destruction, in its turn, impedes and slows down job creation in the corporate sector [Brown, Earle, 2002]. Creation of informal and low-productivity jobs even in large numbers does not solve the problem of stimulating enterprise restructuring;

$=$ high wage flexibility increases poverty within the working population, generates inequality among employed and educated workers, deprives people of formal/institutional social protection, and destroys social cohesion;

= a major price paid for maintaining a high level of employment is a low average wage, which protects formal employment and substitutes for formal unemployment benefits. Low wage jobs can be supported by moon-lighting activity and engagement in low productivity employment in the informal sector. All this leads to inefficient utilization of human capital;

$=$ low transparency in the labour market and strong informational asymmetry in job vacancies and individual productivity. Searching for a job or entering paid employment in this type of the labour market, an individual faces high uncertainty since he/she cannot foresee future earnings. This increases individual search and adjustment costs, including moral costs associated 
with search behaviour, generates voluminous and inefficient churning (short-term job matches), and negatively affects the efficiency of labour reallocation;

= survival of numerous loss-making firms produces inefficient matching: many workers stay at jobs where they don't have comparative advantages in productivity while search for such jobs is costly and very slow;

$=$ high labor turnover weakens incentives for further investment in the human capital, including on-the job-training provided by firms. Instead of investing in specific human capital, employers prefer to hire job candidates with better general human capital, which is often considered the only reliable labour market signal;

= incomplete law and contract enforcement opens room for opportunistic behavior of employers and makes shifting adjustment costs onto workers easier (through wage arrears, ousting redundant workers through quits without severance pay, etc);

$=$ devaluation of formal labor contracts generates low trust behaviour and shortens the horizon for decision-making with detrimental consequences for the rule of law. The state loses the ability to be an arbiter trusted by all parties. It itself violates formal rules and "spoils" other agents as well.

The general conclusion from this balance-sheet is that the Russian labor market helps to buffer various shocks but is not friendly to restructuring and to coping with competitive pressures. However, since labor market outcomes are determined by many powerful factors outside the labor market per se, one can speculate that the Russian model was the best available in the given circumstances of the deep recession, macroeconomic and political uncertainty, and unfriendly institutional environment. The choice of this particular model was highly inertial at all stages of the transition period. Its conservation at the stage of economic growth contributed to distorting and slowing down the restructuring process. All that suggests also that the partial positive implications of the model emerge as a second best outcome from the actual circumstances and policies.

The Russian labor market institutions are - as we can see - complements; they form an institutional equilibrium. In the given institutional environment major market agents emerge as beneficiaries. This makes the model robust to occasional interventions and brings strong path dependence. It has survived several shifts in macroeconomic regimes, a few attempts at partial reform, and four external macroshocks. Despite all this, its modus operandi has changed little. Moreover, some adjustment mechanisms, which had seemed to disappear under governmental pressure or during the growth episodes, came back as soon as a new crisis emerged. Such path dependence makes radical restructuring of the institutional core of the model a formidable 
challenge. In order to solve the equation, the government should move simultaneously in two different directions. On the one hand, labor market regulations need to become simpler, more transparent and less costly for major actors. On the other, enforcement of laws and contracts should be improved radically. These strategies should complement each other, being two sides of the same policy. The Russian experience suggests that reforming the model from above does not work well. However, if large-scale domestic and foreign investment would have come in to set up enterprises across the country to take the place of the dying enterprises and to bring new technological and organizational know-how, then its gradual reformatting could emerge from below. But the chances this can be achieved in the mid-term perspective are slim. Therefore, the specific features of the Russian labor market that were discussed above are likely to be reproduced and observed in the future.

\section{Bibliography}

1. Aghion, Ph., Y.Algann, P.Cahuc and A. Shleifer. «Regulation and Trust», The Quarterly Journal of Economics (2010) 125(3): 1015-1049

2. Alfandari, G., and M. E. Shaffer. Arrears in the Russian Enterprise Sector / In: Enterprise Restructuring and Economic Policy in Russia, ed. by S. Commander, Q. Fan and M. E. Shaffer. Washington, DC: EDI/World Bank 1996.

3. Ashwin S., Clarke S. Russian Trade Unions and Industrial Relations in Transition. Basingstoke and New York: Palgrave. 2002.

4. Bertola G. Job Security, Employment and Wages // European Economic Review. 1990. Vol. 34. No. 4. P. 851-886.

5. Bigsten A., Collier P., Dercon S., Fafchamps M., Gauthier B., Gunning J. W., Oduro A., Oostendorp R., Pattillo C., Soderbom M., Teal F., and A. Zeuback. Risk Sharing in Labor Markets // The World Bank Economic Review. 2003. Vol. 17. No. 3. P. 349-366.

6. Blanchflower D. Fear, Unemployment and Pay Flexibility // Economic Journal. 1991. Vol. 101. No. 406. P. 483-496.

7. Boeri T. Transition with Labour Supply. Bonn: IZA. 2001. IZA Discussion Paper No. 257.

8. Boeri T. and K. Terrell. Institutional Determinants of Labor Reallocation in Transition // Journal of Economic Perspectives. Vol. 16. No.1. 2002. P. 51-76.

9. Botero J.C., Djankov S., La Porta R., Lopez-de-Silanes F., Shleifer A. The Regulation of Labor // The Quarterly Journal of Economics. 2004. Vol. 119. No. 4. P. 1339-1382. 
10. Brown, J. David \& Earle, John S. Gross Job Flows in Russian Industry Before and After Reforms: Has Destruction Become More Creative? // Journal of Comparative Economics. 2002. Vol. 30. No. 1. P. 96-133.

11. Brown D., Earle J., Gimpelson V., Kapeliushnikov R., H. Lehmann, Á. Telegdy, I. Vantu, R. Visan, A. Voicu. Nonstandard Forms and Measures of Employment and Unemployment in Transition: A Comparative Study of Estonia, Romania, and Russia. // Comparative Economic Studies. 2006. Vol. 48. No. 3. P.435-457.

12. Cahuc P., S. Carcillo. Is Short-Time Work a Good Method to Keep Unemployment Down? IZA DP No. 5430, January 2011.

13. Cazes S., Do Labour Market Institutions Matter in Transition Economies? An Analysis of Labour Market Flexibility in the Late Nineties. Geneva: ILO. 2002. International Institute for Labour Studies. Discussion Paper No. 140/2002

14. Cazes S., Nesporova A. Towards excessive job insecurity in transition economies? Geneva: ILO. 2001. Employment Paper 2001/23.

15. Clarke S. Structural Adjustment without Mass Unemployment? / In Clarke S. (ed.) Structural Adjustment without Mass Unemployment? Lessons from Russia. Cheltenham Brookfield: Edward Elgar Publishing. 1998a.

16. Clarke S. Trade Unions and the Non-Payment of Wages in Russia // International Journal of Manpower. 1998b. Vol.19. No 1/2. P. 68-94.

17. Clarke S. The State of the Russian Unions // Journal of Labor Research. 2007. Vol. XXVIII. No. 2. P. 275-299.

18. Commander S. and Schankerman M. Enterprise Restructuring and Social Benefits // Economics of Ttransition. 1997. Vol. 5. No. 1. P. 1-24.

19. Commander S., Tolstopiatenko A. Why is Unemployment Low in the Former Soviet Union? Policy Research Paper 1617. Washington D.C.: The World Bank. 1996.

20. Commander S., and A. Tolstopyatenko. Unemployment, Restructuring and the Pace of Transition / In: Zecchini, S., ed. Lessons from the Economic Transition. Central and Eastern Europe in the 1990s. Dordrecht: Kluwer Academic Publishers. 1997.

21. Denisova I., Svedberg M. The Governance of Economic and Employment Development in North West Russia / Giguere S. (ed.) Baltic Partnerships: Integration, Growth, and Local Governance in the Baltic Sea Region. Paris: OECD. 2007.

22. Desai, P., and T. Idson. Work Without Wages: Russia's Non-payment Crises. Cambridge, Mass.: The MIT Press. 2000. 
23. Earle J. S., Sabirianova K. Z. Equilibrium Wage Arrears: A Theoretical and Empirical Analysis of Institutional Lock-In. Bonn: IZA. 2000. IZA Discussion Papers 196.

24. Earle J. S., Sabirianova K. Z. How Late to Pay? Understanding Wage Arrears in Russia // Journal of Labor Economics. 2002. Vol. 20. No. 3. P. 661-707.

25. Earle J. S, Spicer A. and Sabirianova Peter K. Community Norms and Organizational Practices: The Legitimization of Wage Arrears in Russia, 1992-1999. Bonn: IZA. 2004. IZA Discussion Papers 1006.

26. Employment Outlook: The Russian Federation. 1992-2000. Moscow: TEIS. 2002 (in Russian).

27. Gimpelson, V. Politics of Labor Market Adjustment (the Case of Russia). In: J. Kornai, Haggard S., and R. Kaufman, ed. Reforming the State: Fiscal and Welfare Reform in Post-Socialist Countries. Cambridge: Cambridge University Press. 2001.

28. Gimpelson V., and D. Lippoldt. The Russian Labour Market: between Transition and Turmoil. L.: Roman \& Litlefield. 2000.

29. Gimpelson V.E., Kapelyushnikov R., Lukiyanova A. Employment Protection Legislation in Russia: Regional Enforcement and Labour Market Outcomes // Comparative Economic Studies. 2010. Vol. 24. No. 3. C.311-332.

30. Gimpelson V, A. Oshchepkov. Fear of Unemployment: Determinants and Implications. The HSE Discussion Paper WP3/2010/06. Moscow, 2010 (in Russian).

31. Heckman J., Pagés C. Law and Employment: Lessons from Latin America and the Carribean. NBER. 2003. Working Paper No. 10129.

32. Kapelyushnikov R.I. The Russian Labor Market: Adjustment without Restructuring. Moscow: State University - Higher School of Economics. 2001 (in Russian).

33. Kapelyushnikov R. General and Registered Unemployment: What are the Reasons for the Gap? Working Paper WP3/2002/01. Moscow: State University - Higher School of Economics. 2002 (in Russian).

34. Kapelyushnikov R How to Evaluate the EPL Strictness in Russia: A Comment. Higher School of Economics Working Paper WP3/2011/02, 2011 (in Russian).

35. Layard, R., and A. Richter. Labour Market Adjustment - the Russian Way / In: A. Aslund, ed., Russian Economic Reform at Risk. London: Penter. 1995a.

36. Layard R., Richter A. How Much Unemployment is Needed for Restructuring // Economics of Transition. 1995b. Vol. 3. No. 1. P. 39-58. 
37. Lazear E.P. Job Security Provisions and Employment // The Quarterly Journal of Economics. 1990. Vol. 105. No. 3. P. 699-726.

38. Lehmann H., Wadsworth J. Tenures that Shook the World: Worker Turnover in Russia, Poland and Britain // Journal of Comparative Economics. 2000. Vol. 28 No. 4. P. 639-664.

39. Lehmann H., Wadsworth J. Wage Arrears and the Distribution of Earnings in Russia. Bonn: IZA. 2001. IZA Discussion Paper 410.

40. Lehmann H., Wadsworth J. and Acquisti A. Grime and Punishment: Job Insecurity and Wage Arrears in the Russian Federation // Journal of Comparative Economics. 1999. Vol. 27. No. 4. P. 595-617.

41. Linz S and A. Semykhina. How Do Workers Fare during Transition? Perceptions of Job Insecurity among Russian Workers, 1995-2004 // Labour Economics. 2008. Vol. 15. No. 3. P. 442458.

42. OECD. Employment Outlook. Paris: OECD. 1999.

43. OECD. OECD Indicators of Employment Protection. 2010. (http://www.oecd.org/employment/protection)

44. The Russian Statistical Yearbook. Moscow: Rosstat (various issues).

45. Standing G. Russian Unemployment and Enterprise Restructuring: Reviving the Dead Souls. N. Y.: St. Martin Press, 1996.

46. Treisman D. Presidential Popularity in a Hybrid Regime: Russia under Yeltsin and Putin. Forthcoming // American Journal of Political Science. 2011. (forthcoming)

47. UNECE. Some Aspects of Labour Market Performance in Eastern Europe and the CIS // Economic Survey of Europe. 2003. No. 1. P. 191-209.

48. Wages in Russia: Evolution and Differentiation. Gimpelson V. and Kapelyushnikov R., ed. Moscow: State University - High School of Economics. 2007 (in Russian).

49. World Bank. The Russian Labor Market: Moving from Crisis to Recovery. W.: World Bank. 2003.

50. World Bank. Enhancing Job Opportunities: Eastern Europe and the Former Soviet Union. Washington: World Bank. 2005.

51. World Bank. Doing Business (http://www.doingbusiness.org/ExploreTopics/ EmployingWorkers). 2007. 
Fig. 1

\section{Figures $^{21}$}

GDP, Employment, Real Wage and Working Hours in the Russian Economy, 1991-2010, \% $(1991$ г. $=100 \%)$

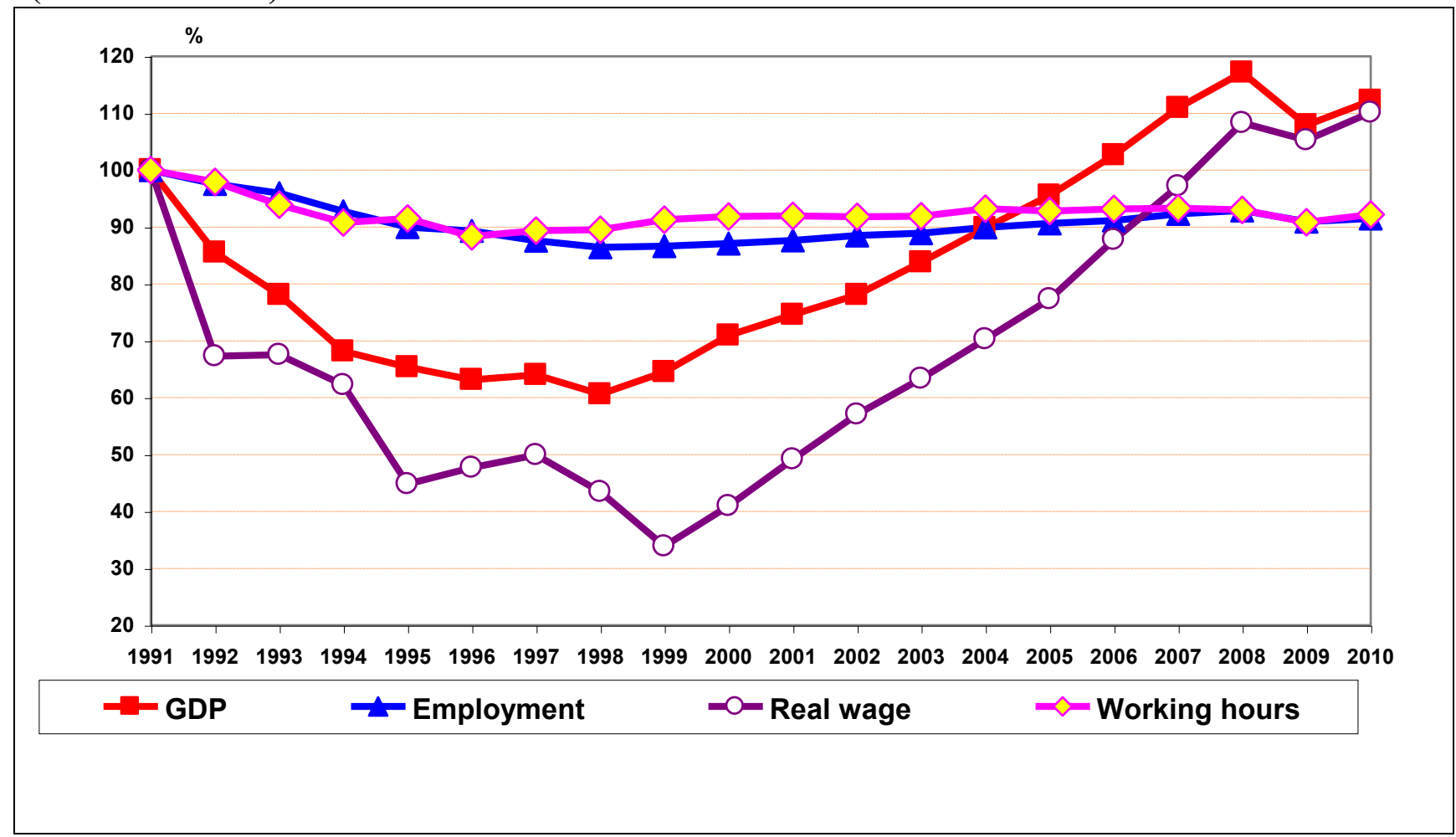

Fig. 2

Evolution of Employment-population ratio, 1992-2009 (population 15-64 years old)

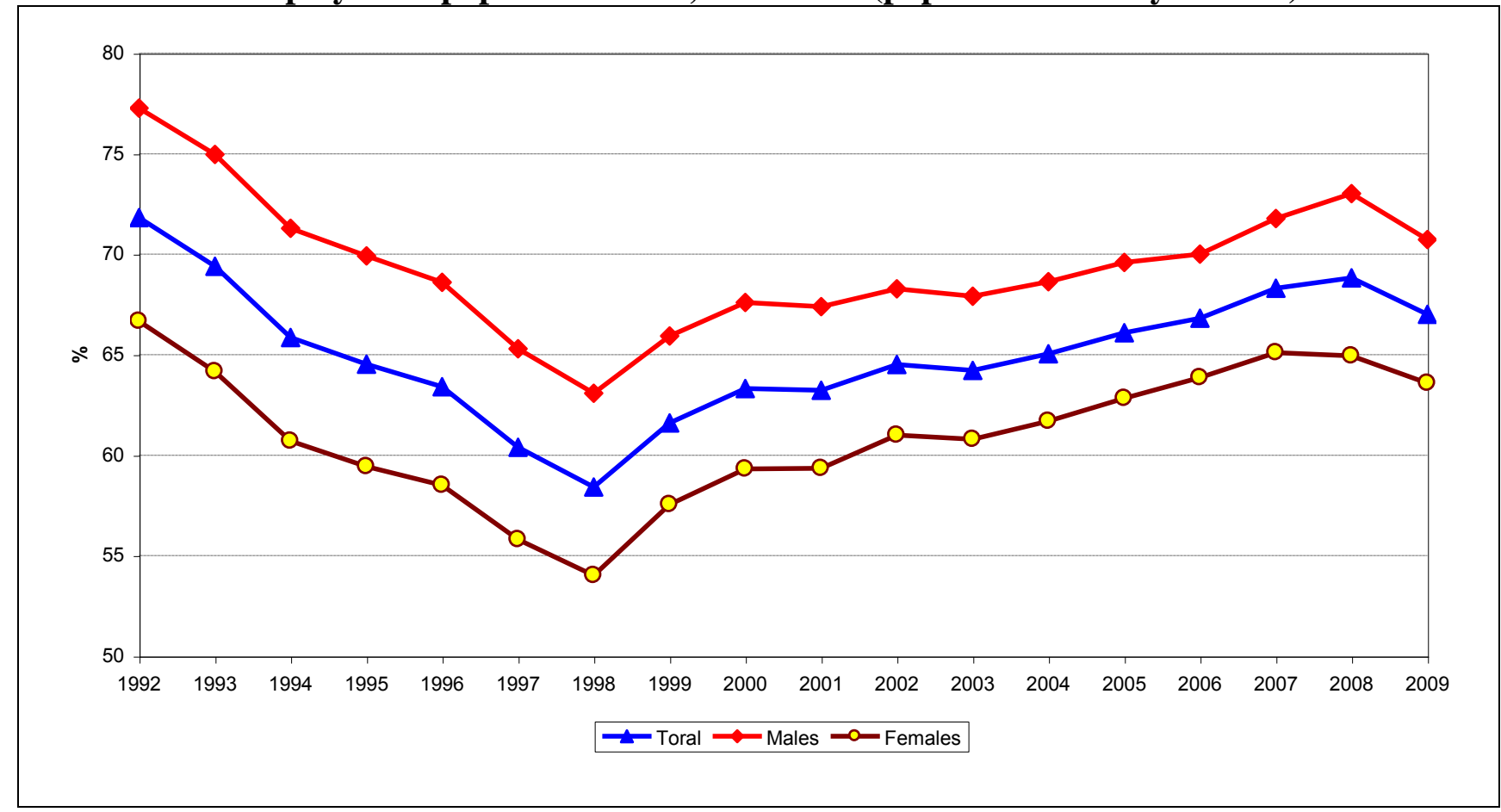

${ }^{21}$ Figures 1-15 are based on ROSSTAT data. 
Fig. 3

General and registered unemployment rates, 1992-2010, \%

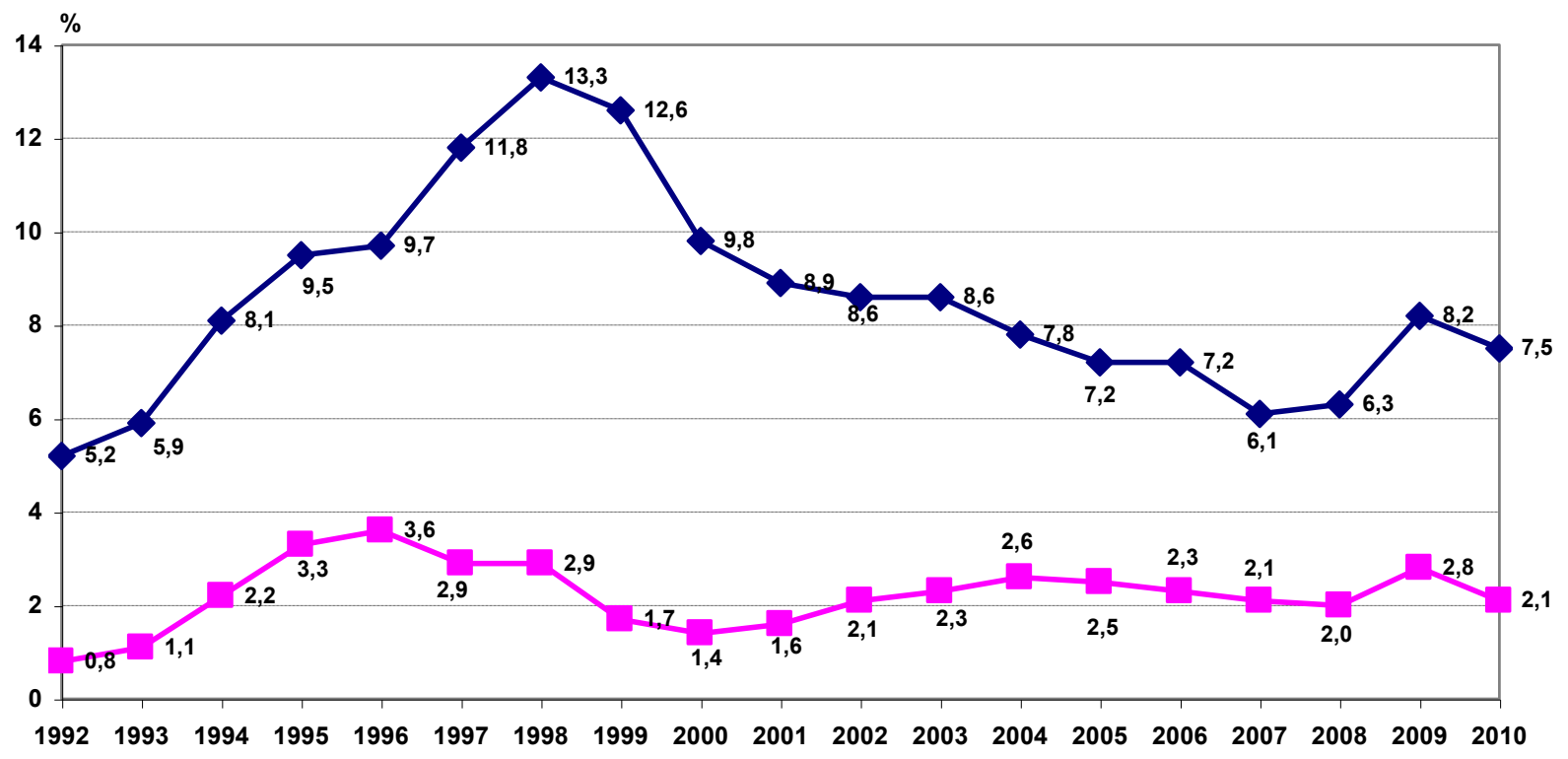

\section{Fig 4}

Evolution of general unemployment in transition countries, 1992-2009, \%

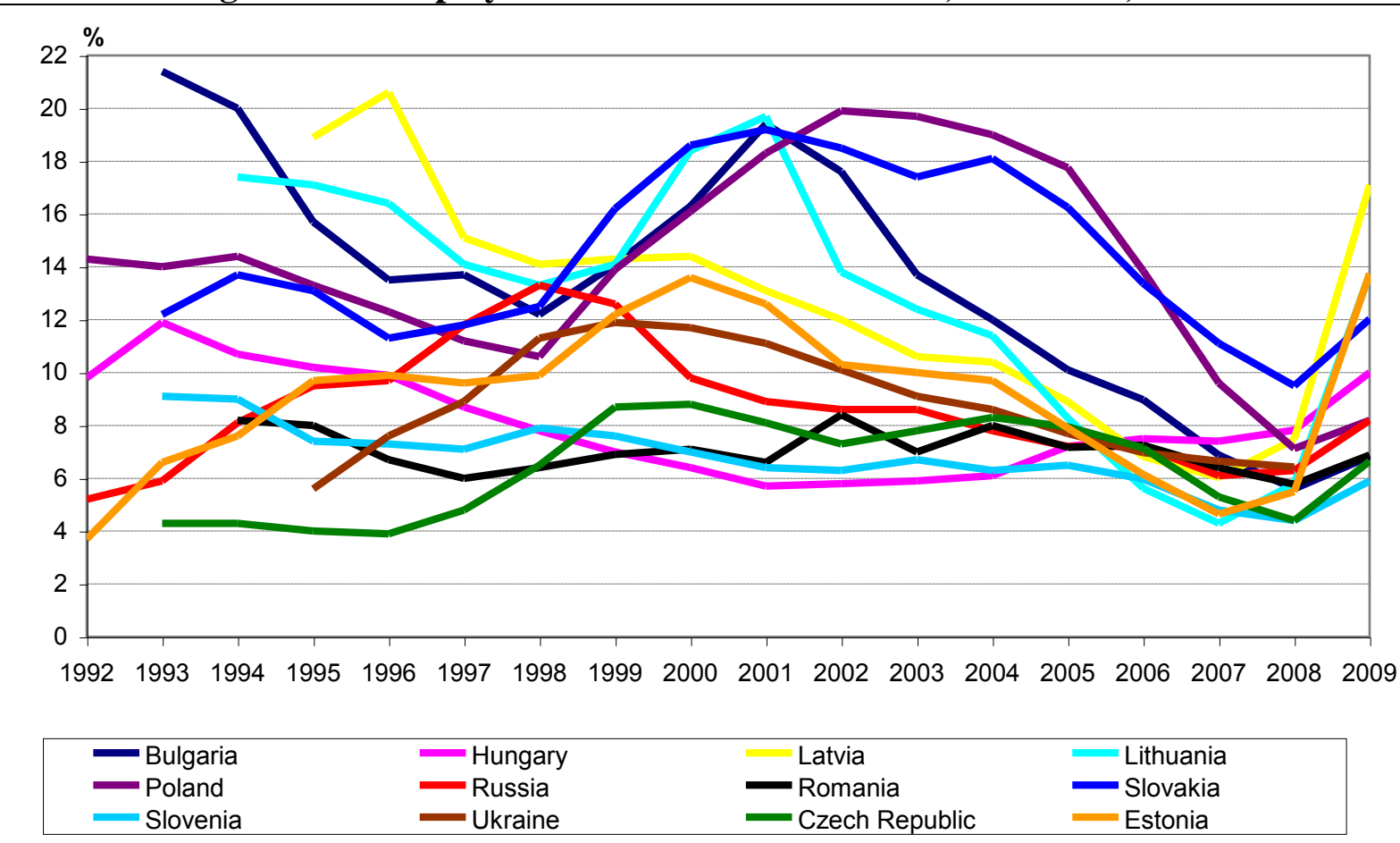


Fig. 5

Evolution of registered unemployment in transition countries, 1992-2009, \%

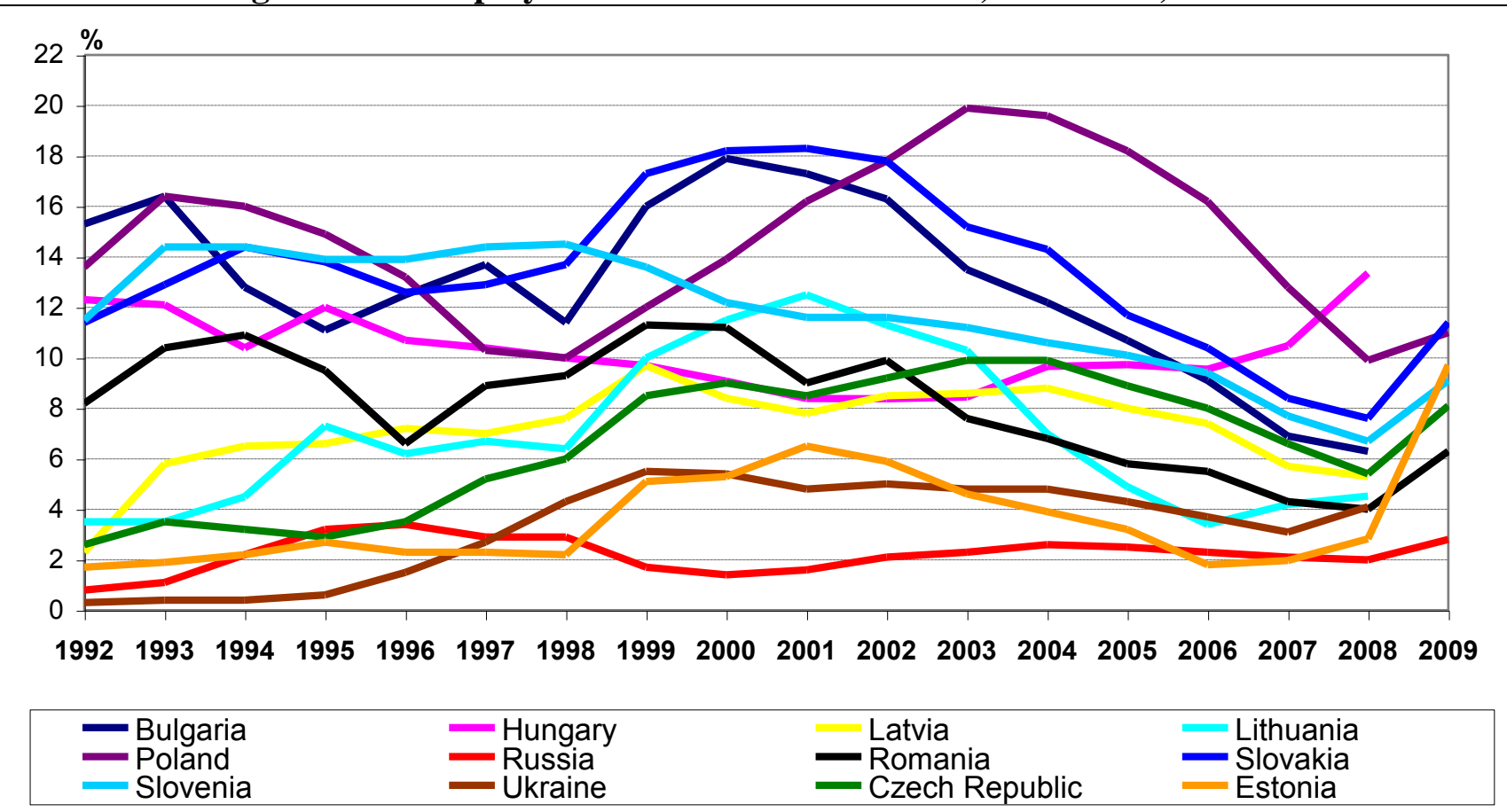

Fig. 6

Worker turnover in the Russian economy, 1992-2009, \%

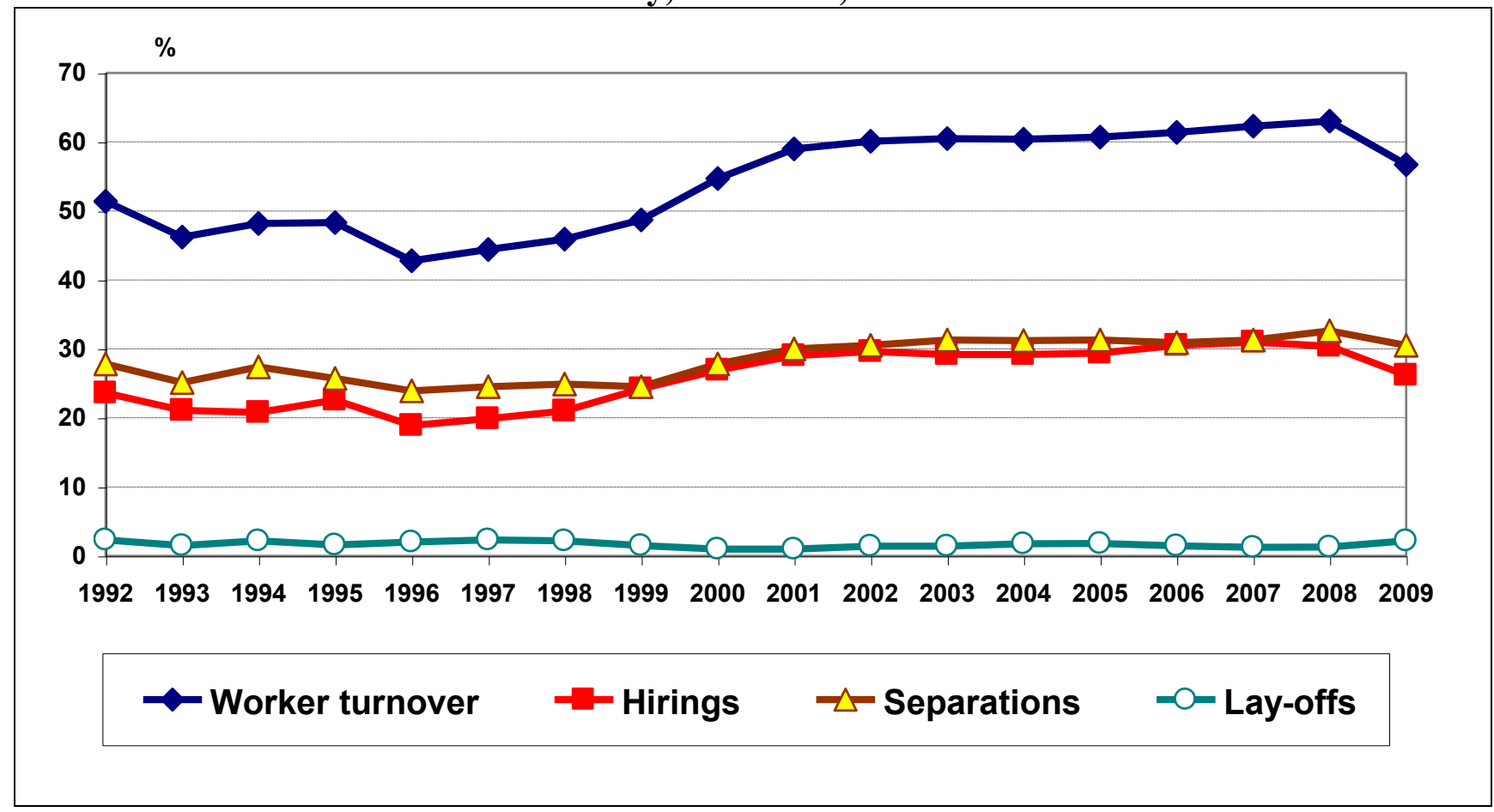


Fig. 7

Annual working hours per worker, 1992-2010

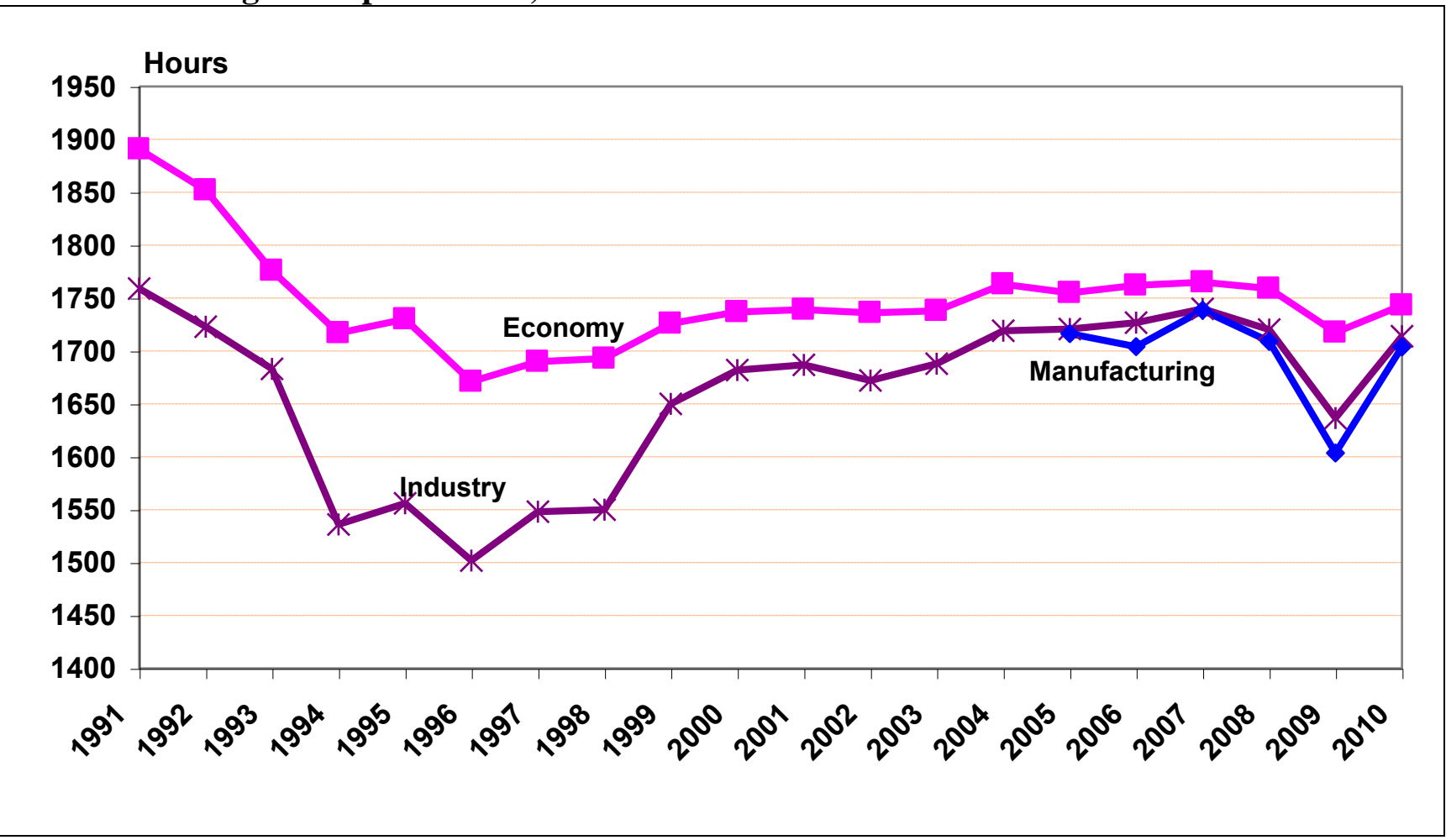

Fig. 8

Underemployment in large and medium sized enterprises, 1993-2009, \%

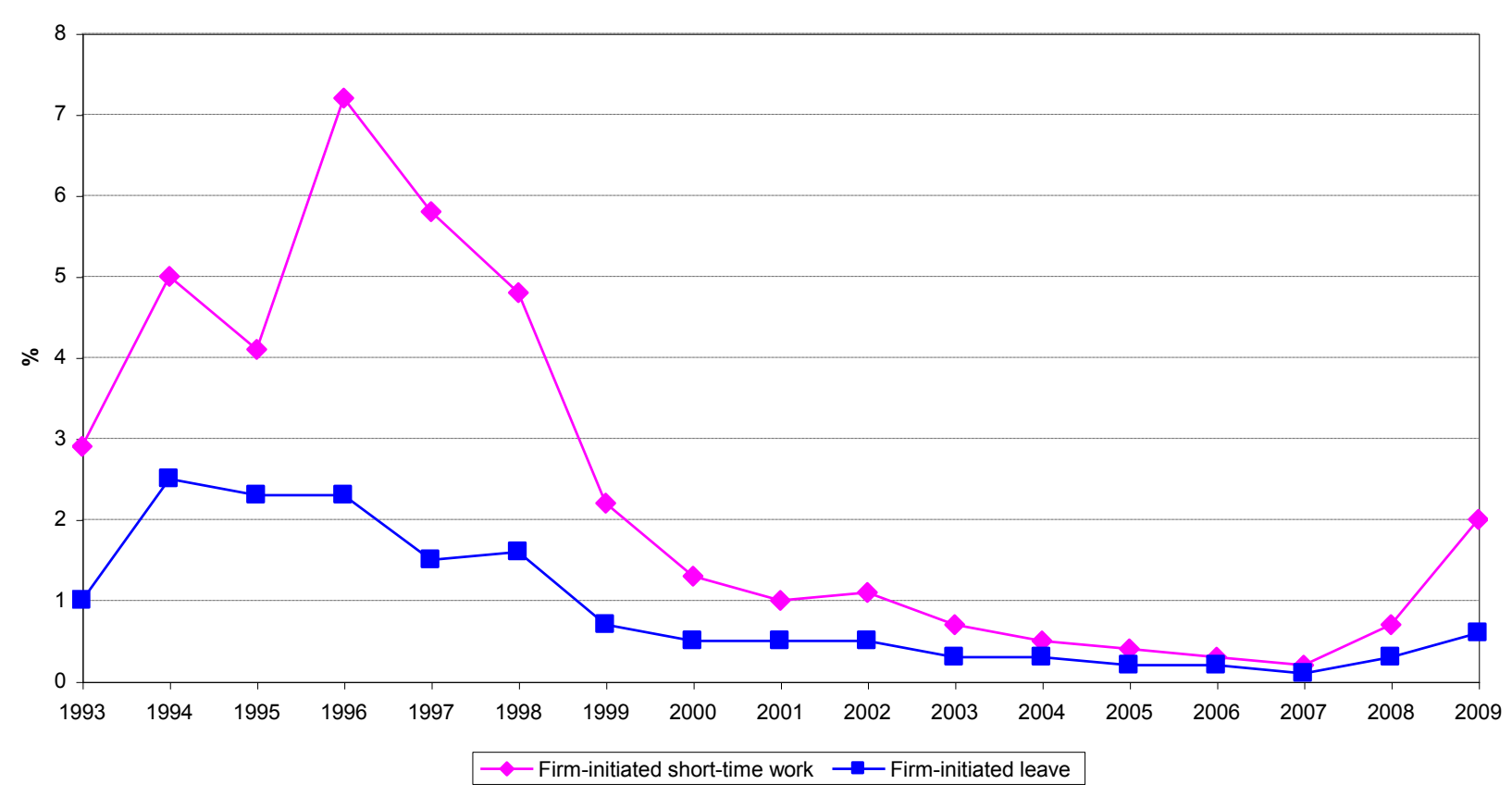


Fig. 9

Wage arrears deflated by CPI, 1992-2010, billion of Rubles (March 1992 CPI = 100\%)

bln. Rubles

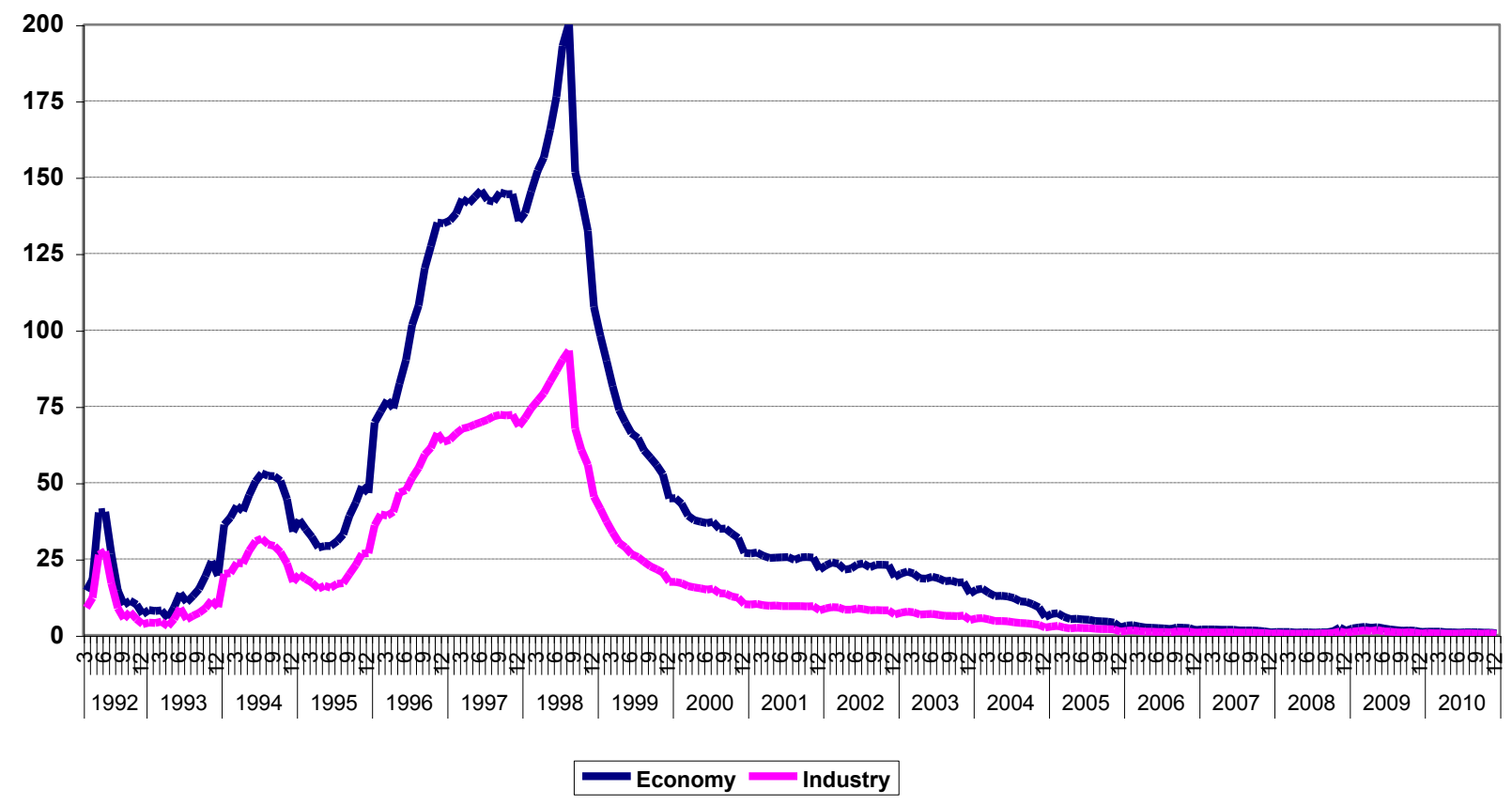

Fig 10

Monthly indices of employment and real wage, 1991-2010, \% (January 1991 = 100\%)

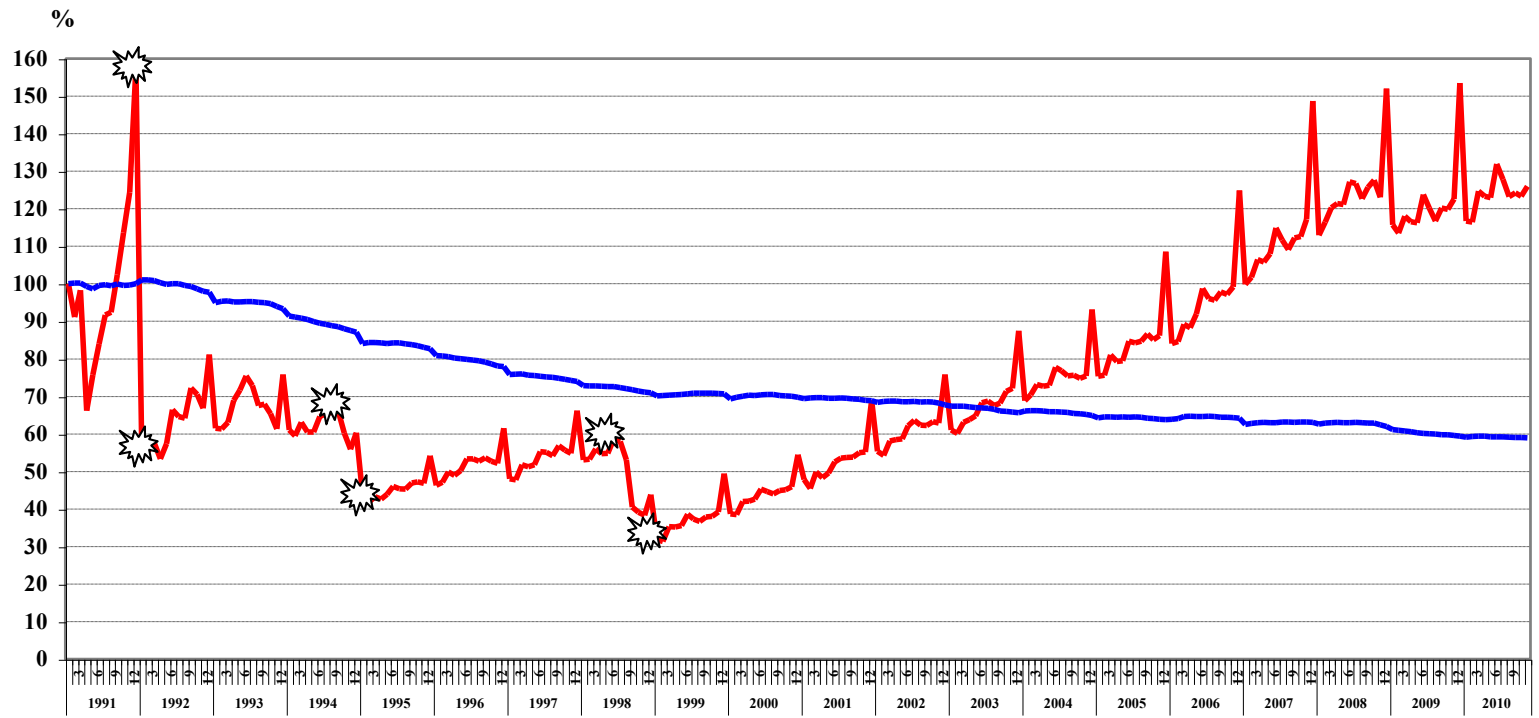

Monthly index of real wage Monthly index of employment 
Fig. 11

Monthly levels of general and registered unemployment in the Russian economy, 1999-2010, $\%$

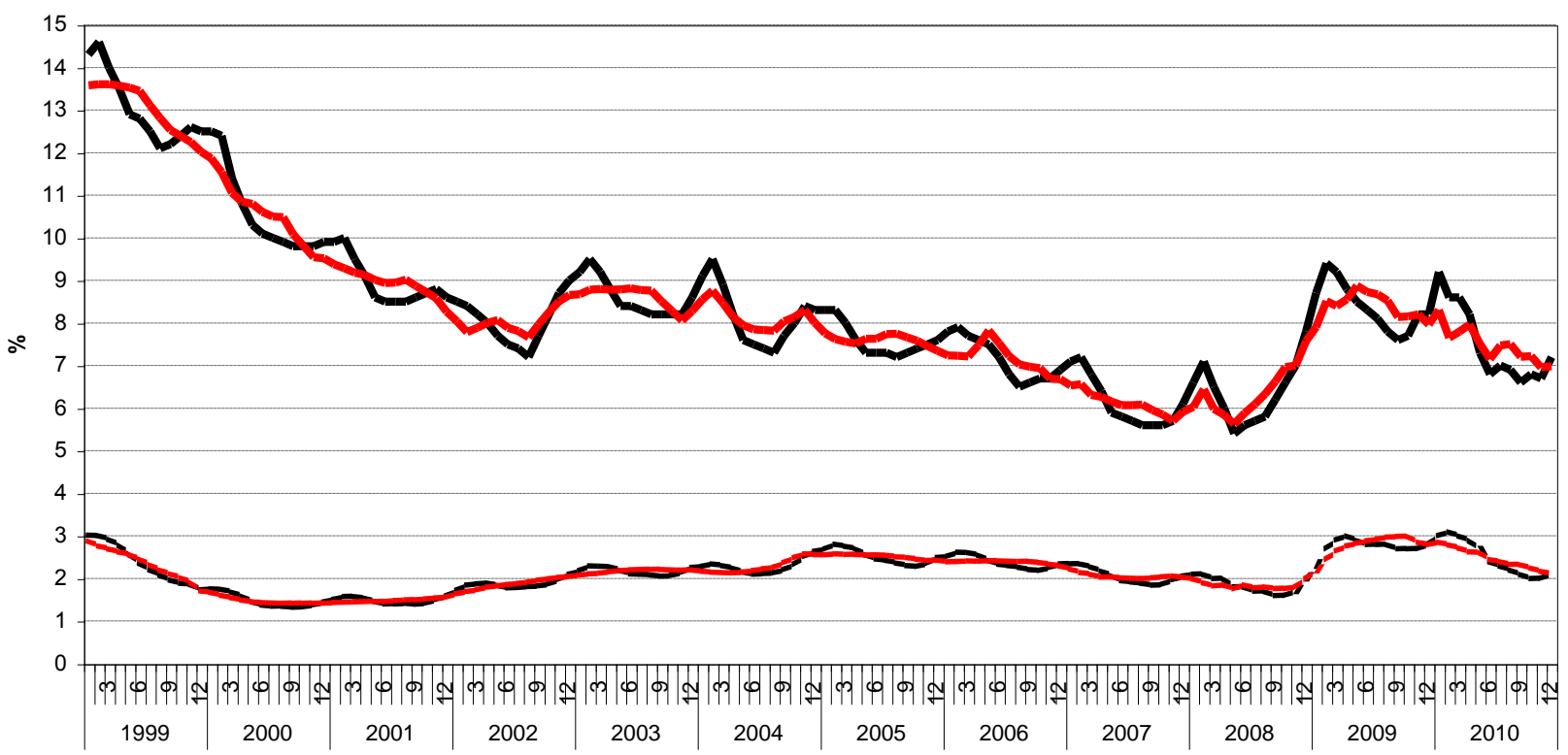

$\begin{array}{ll}\text { - General unemployment (seasonally unadjusted) } & =\text { General unemployment (seasonally adjusted) } \\ \text { - - - Registered unemployment (seasonally unadjusted) } \quad \text { - - - Registered unemployment (seasonally adjusted) }\end{array}$

Fig. 12

Monthly indicators of delayed wage payments, 2005-2010

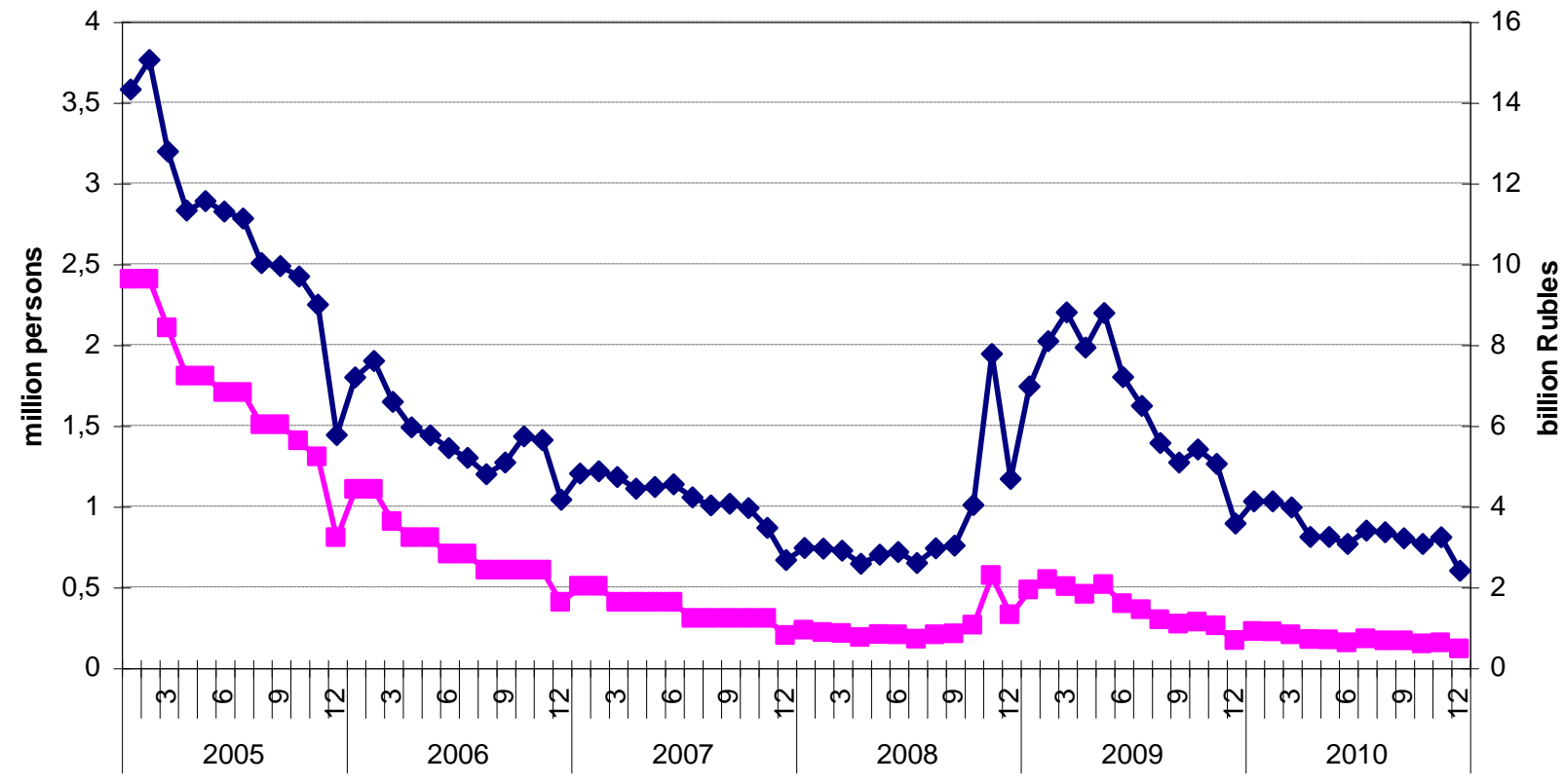

- Number of employees with due wages

$\rightarrow$ Wage arrears 
Fig. 13

Twelve-months indices of nominal and real wage growth, 2006-2010, \%

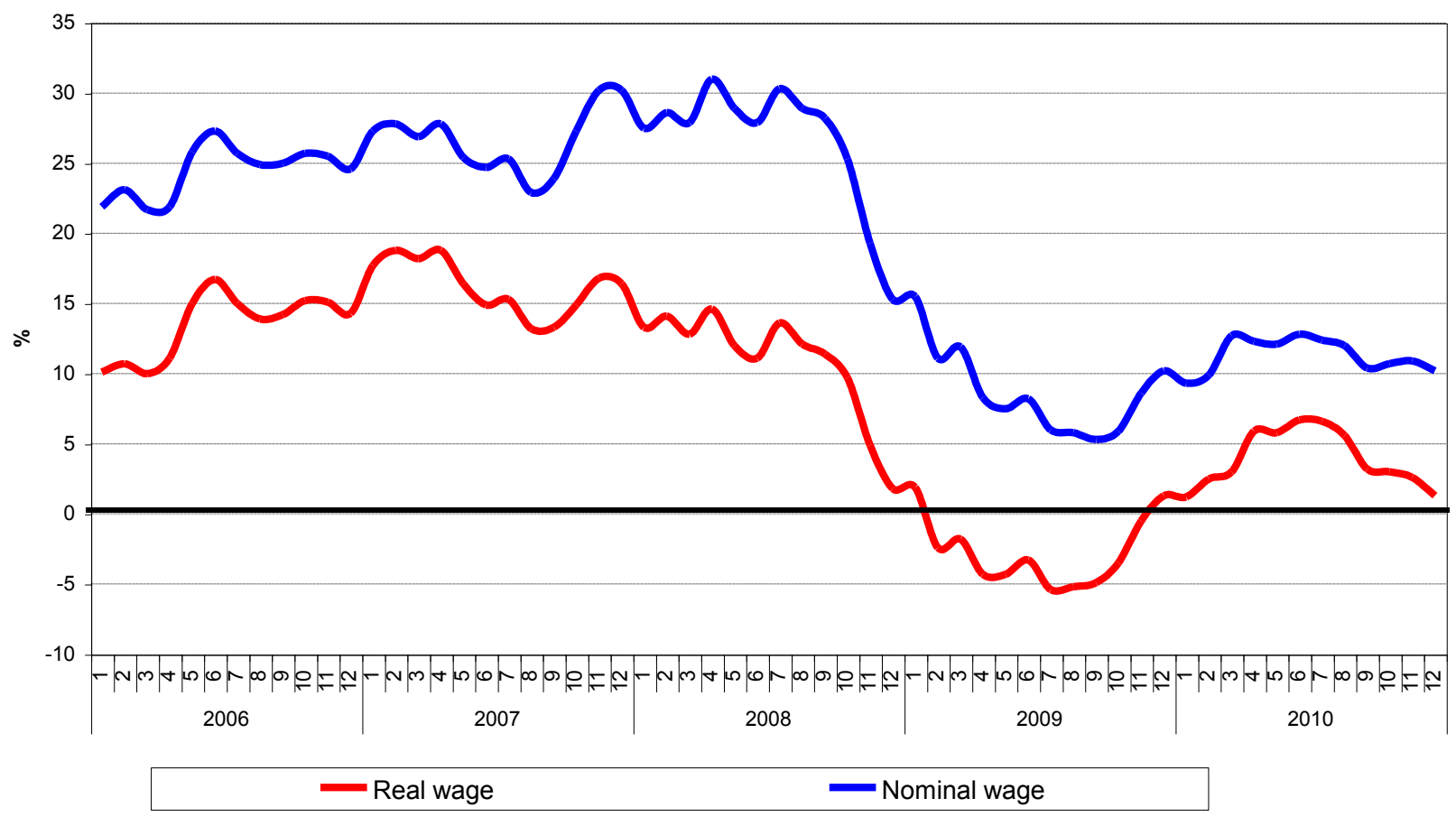

Fig.14

Minimum to Average Wage Ratio, \%, 1992-2010

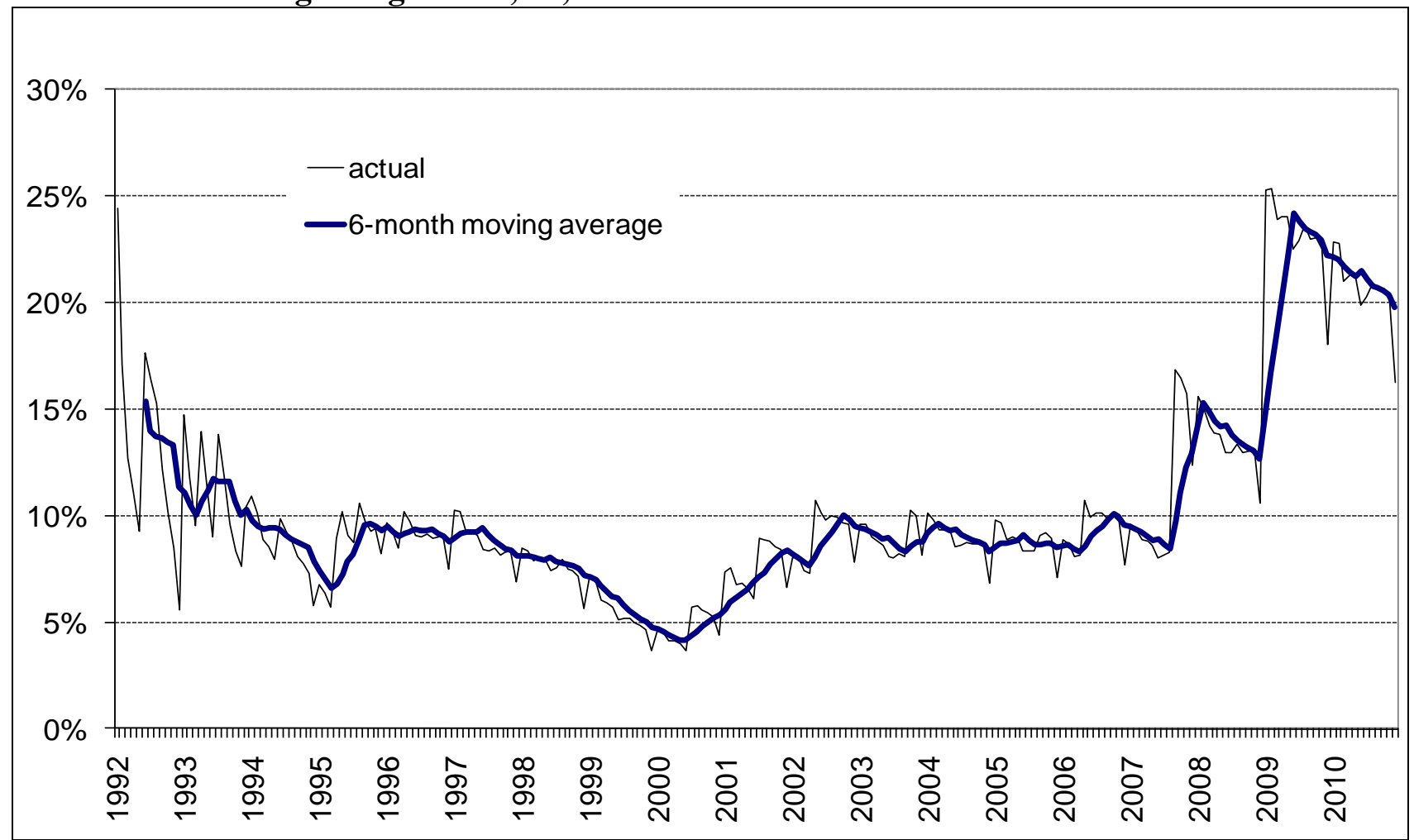


Fig 15

Unemployment Benefits and Average Wage, 1992-2010

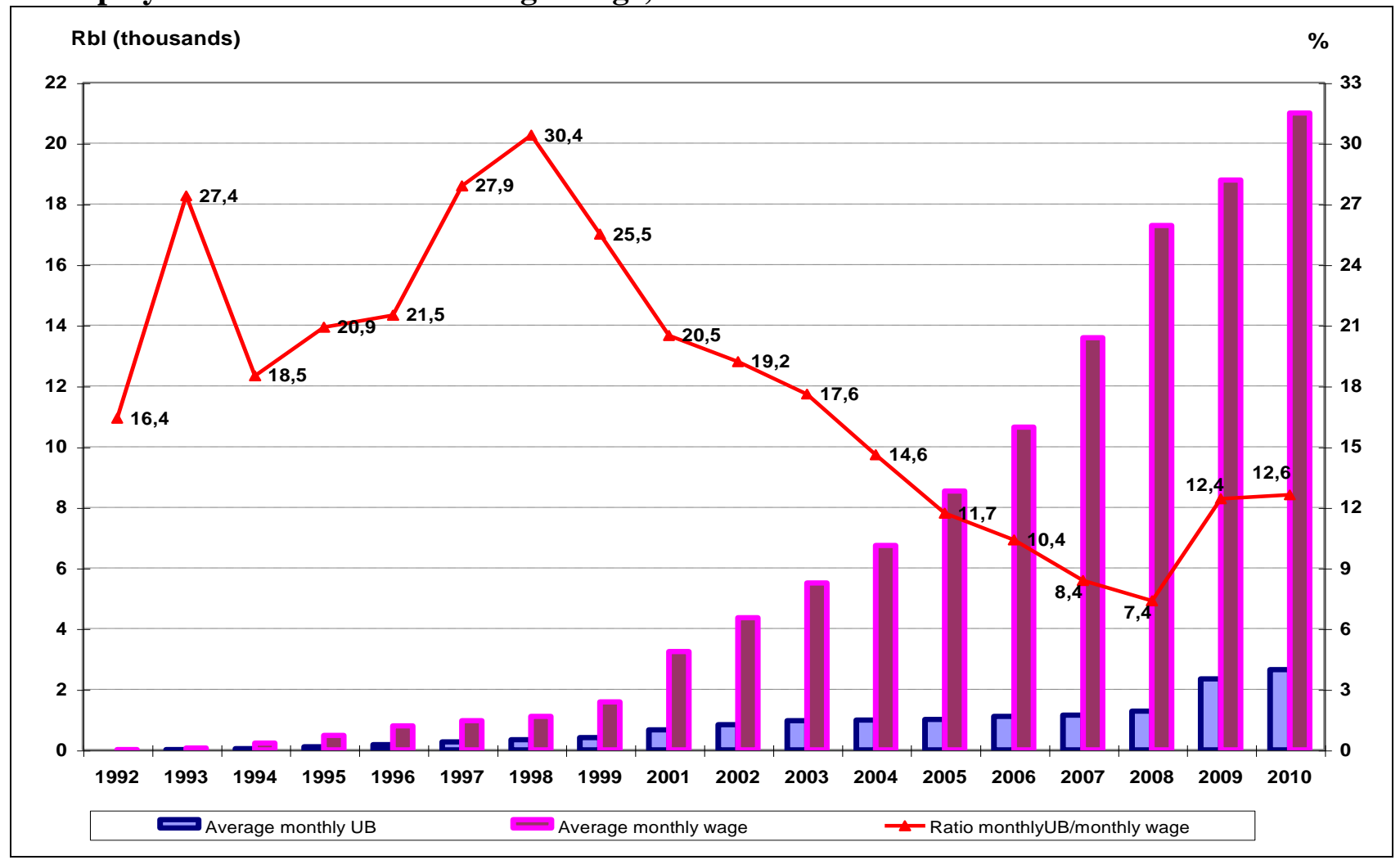

Fig. 16

How the Russian Model Works: A Stylized Picture

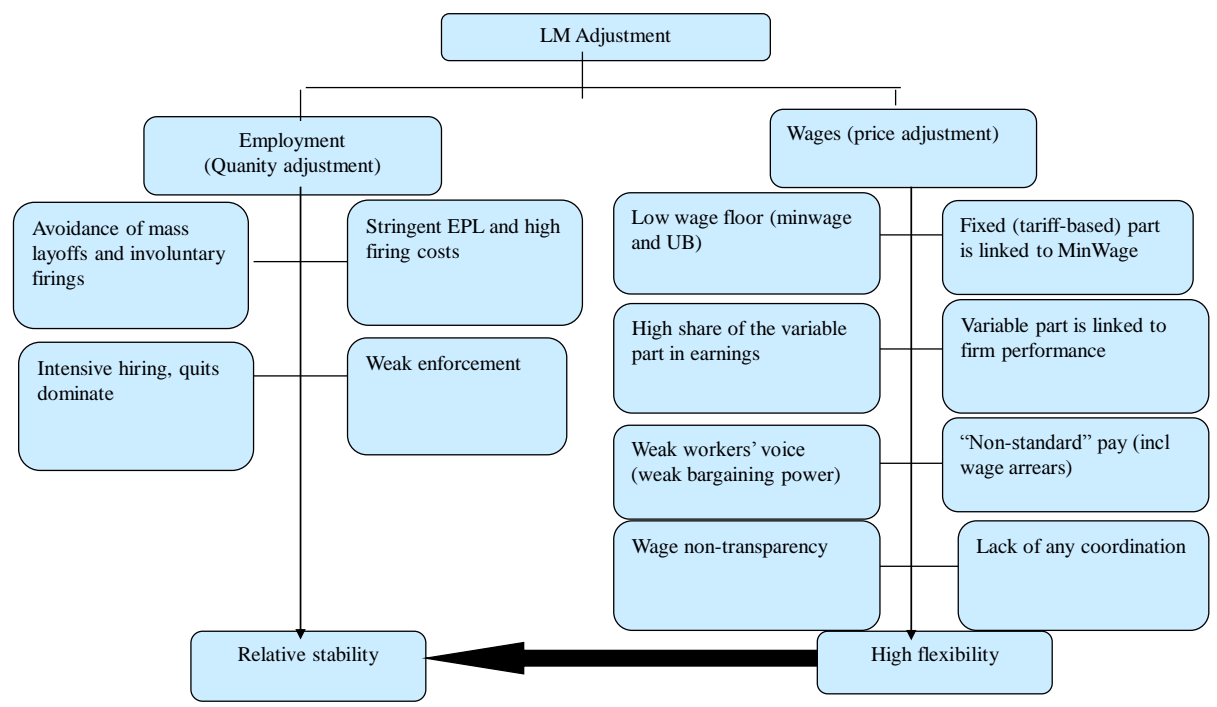

